\title{
Creep of Cold-Drawn Nickel, Copper, 70 Percent Nickel- 30 Percent Copper, and 30 Percent Nickel-70 Percent Copper Alloys
}

\author{
William D. Jenkins and William A. Willard
}

(August 17, 1961)

\begin{abstract}
Creep tests were made in tension under constant loads at temperatures of $300,700,900$ and $1,200^{\circ} \mathrm{F}$ on nickel, copper, 70-percent nickel-30-percent copper, and 30-percent-nickel70 -percent copper specimens, initially cold-drawn to 40-percent reduction in area. Conformance to the conventional creep rate laws was obtained only over limited ranges of stresses, temperatures, creep rates, and strains. Metallographic examinations were carried out on some of the fractured specimens to ascertain the effects of temperature and stress on the necking characteristics, internal cracking, subgrain formation and the number and distribution of "etch figures." The relations between cold-drawing and the creep characteristics are discussed.
\end{abstract}

\section{Introduction}

A comprehensive investigation, designed to evaluate the effects of stress and temperature on the mechanical properties of metals, has been in progress for several years at the National Bureau of Standards. Some of the results of tests made on nickel, copper, and nickel-copper alloys have been published [1 to 9]. ${ }^{1} \quad$ The present phase of the study was made to evaluate the effects of stress and temperature on the creep characteristics at $300,700,900$, and $1,200{ }^{\circ} \mathrm{F}$ of nickel, copper, 70 percent nickel-30 percent copper, and 30 percent nickel-70 percent copper specimens, as cold-drawn to 40 percent reduction in area. Some creep data, obtained on the annealed metals [8], made from the same heats as those used in the present studies, are included to evaluate the relations between cold-drawing and creep behavior.

Extensive reviews of current literature on theories of solid-solution alloying [10] and of creep [11] have recently been presented. Therefore, orly selected references, pertinent to the present data, are listed.

\section{Materials and Procedures}

The chemical compositions of each of four metals used is given in table 1. All the bars of each material were processed from a single heat and they were supplied in the form of $7 / 8$ or ${ }^{13} 16^{6}$-in. rounds. The annealing treatments produced average grain sizes as shown in table 1 and these annealing treatments were used prior to the final cold-drawing of the rods to 40-percent reduction in area. The creep specimens of each metal for each condition were machined from a single bar and had a 0.505-in. diam over a 2 -in. reduced section.

\footnotetext{
1 Figures in brackets indicate the literature references at the end of this paper.
}

Each specimen was heated for $24 \mathrm{hr}$ in air at the desired temperature before loading to a predetermined stress in increments of approximately 5,300 psi, applied at $1-\mathrm{hr}$ intervals. The temperatures of the creep furnaces were controlled to $\pm 1{ }^{\circ} \mathrm{F}$ of the desired values over the specimen length and the probable error in measuring the extension increments was less than 0.00002 in.

\section{Results and Discussion}

The data are summarized in table 2 , and in figures 1 to 16 inclusive. The relation between cold-drawing and the creep characteristics of nickel was previously described [9]. Some of these data on the nickel are used in this paper for comparison purposes. The relation of cold-drawing to the creep characteristics of the other metals used were essentially similar when comparisons were made at equel test temperaturerecrystallization temperature ratios. These relations are generally illustrated, in this paper, by the data obtained on the 30 percent nickel-70 percent copper alloy specimens.

\subsection{Effects of Stress and Temperature on Strain- Time Relations}

Numerous equations have been proposed to describe the strain-time relations for specimens tested at different temperatures and stresses. However, the equations generally are applicable only to specific stages of creep over limited ranges of stresses within definite temperature limits and in some cases are empirically derived. In spite of the similarity of strain-time curves obtained under various test conditions, it is not feasible to derive another complete strain-time curve by simple transposition even for specimens of the same metal tested at the same tem- 
TABLE 1. Chemical composition and grain sizes of metals

\begin{tabular}{|c|c|c|c|c|c|c|c|c|c|c|c|c|c|}
\hline \multirow{2}{*}{ Metal } & \multicolumn{12}{|c|}{ Chemical composition, wt\% } & \multirow{2}{*}{$\begin{array}{l}\text { Averagec } \\
\text { grain } \\
\text { diameter }\end{array}$} \\
\hline & $\mathrm{C}$ & $\mathrm{Cu}$ & $\mathrm{Ni}$ & Co & $\mathrm{Fe}$ & Mn & $\mathrm{Si}$ & $\mathrm{s}$ & $\mathrm{Zn}$ & $\mathrm{O}_{2}$ & $\mathrm{~N}_{2}$ & $\mathrm{H}_{2}$ & \\
\hline $\begin{array}{l}\text { Coppera }(\mathrm{OFHC}) \\
30 \%-\mathrm{Ni}-70 \% \mathrm{Cu} \\
70 \%-\mathrm{Ni}-30 \% \mathrm{Cu} \\
\text { Nickel }\end{array}$ & $\begin{array}{r}0.023 \\
.017 \\
.007\end{array}$ & $\begin{array}{l}99.99+ \\
68.84 \\
29.71 \\
0.009\end{array}$ & $\begin{array}{l}29.89 \\
70.08 \\
99.85\end{array}$ & $\begin{array}{l}0.04 \\
b \\
b\end{array}$ & $\begin{array}{r}0.50 \\
.01 \\
.04\end{array}$ & $\begin{array}{r}0.65 \\
.01 \\
.03\end{array}$ & $\begin{array}{l}0.003 \\
.12 \\
.11\end{array}$ & $\begin{array}{r}0.004 \\
.002 \\
.002\end{array}$ & 0.09 & $\begin{array}{r}0.001 \\
.001 \\
.002\end{array}$ & $\begin{array}{l}0.001 \\
.0015 \\
.001\end{array}$ & $\begin{array}{r}0.0002 \\
.0003 \\
.0002\end{array}$ & $\begin{array}{r}m m \\
0.025 \\
.040 \\
.025 \\
.045\end{array}$ \\
\hline
\end{tabular}

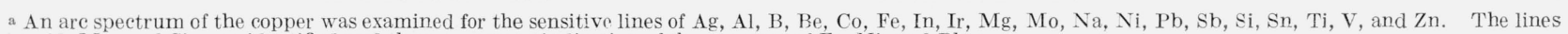
for $\mathrm{Ag}, \mathrm{Al}, \mathrm{Mg}$, and $\mathrm{Si}$ were identified and there was some indication of the presence of $\mathrm{Fe}, \mathrm{Ni}$, and $\mathrm{Pb}$.

b Not detected.

c Values obtained on specimens prepared from the annealed bars.

TABLE 2.-Test conditions and results of creep tests on high-purity nickel, initially cold-drawn to 40 -percent reduction in area

\begin{tabular}{|c|c|c|c|c|c|c|c|c|c|c|c|c|c|}
\hline \multirow[b]{2}{*}{ Specimen } & \multirow{2}{*}{$\begin{array}{l}\text { Test } \\
\text { temper- } \\
\text { ature }\end{array}$} & \multirow{2}{*}{$\begin{array}{l}\text { Creep } \\
\text { stress }\end{array}$} & \multicolumn{2}{|c|}{ Plastic strain } & \multirow{2}{*}{$\begin{array}{l}\text { Average } \\
\text { creep } \\
\text { rate, } \\
\text { second } \\
\text { stage }\end{array}$} & \multicolumn{2}{|c|}{$\begin{array}{l}\text { Beginning of } \\
\text { third stage }\end{array}$} & \multicolumn{5}{|c|}{ End of test } & \multirow[b]{2}{*}{ Remarks } \\
\hline & & & $\begin{array}{l}1 \text { hour } \\
\text { after } \\
\text { appli- } \\
\text { cation } \\
\text { of load }\end{array}$ & $\begin{array}{c}\text { Inter- } \\
\text { cept at } \\
\text { zero } \\
\text { time }\end{array}$ & & Time & $\begin{array}{c}\text { Plastic } \\
\text { stain }\end{array}$ & Time & $\begin{array}{l}\text { Elonga- } \\
\text { tion }\end{array}$ & $\begin{array}{l}\text { Reduc- } \\
\text { tion of } \\
\text { area }\end{array}$ & $\begin{array}{l}\text { True strain } \\
\text { at fracture }\end{array}$ & $\begin{array}{l}\text { True stress } \\
\text { at fracture }\end{array}$ & \\
\hline A-17 & ${ }^{\circ}{ }^{1}$ & $\begin{array}{l}l b / \text { in }^{2} \\
72,000\end{array}$ & $\begin{array}{l}\% \\
0.15\end{array}$ & $\begin{array}{l}\% \\
0.46\end{array}$ & $\begin{array}{c}\% / 1,000 h r \\
0\end{array}$ & $h r$ & $\%$ & $\begin{array}{r}h r \\
2,297\end{array}$ & $\begin{array}{l}\% \\
\mathrm{a} 0.46\end{array}$ & $\begin{array}{l}\% \\
\text { b } 0.4\end{array}$ & $\log _{\mathrm{e}}\left(A_{\mathrm{o}} / A\right)$ & $l b /$ in. $^{2}$ & Test stopped in second \\
\hline A-19 & 300 & 75,000 & .47 & .37 & 75 & 2.5 & 0.61 & 3.2 & 18.5 & 76.4 & 1. 442 & 317,000 & $\begin{array}{l}\text { stage. } \\
\text { Tested to complete frac- } \\
\text { ture. }\end{array}$ \\
\hline $\begin{array}{l}A-20 \\
A-10\end{array}$ & $\begin{array}{l}300 \\
700\end{array}$ & $\begin{array}{l}75,600 \\
42,670\end{array}$ & 0 & .13 & 1,270 & $\begin{array}{l}0.15 \\
425\end{array}$ & .32 & 0.25 & 18 & 78. 1 & 1. 518 & 345,000 & Do. \\
\hline$A-4$ & 700 & 48,000 & .11 & .17 & $\begin{array}{r}0.42 \\
. \quad 4.12\end{array}$ & $\begin{array}{r}425 \\
80\end{array}$ & $\begin{array}{l}.25 \\
.5\end{array}$ & $\begin{array}{l}2,091 \\
164.3\end{array}$ & $\begin{array}{l}26.8 \\
23.0\end{array}$ & $\begin{array}{l}82.1 \\
83.4\end{array}$ & $\begin{array}{l}\text { 1. } 722 \\
1.793\end{array}$ & $\begin{array}{l}238,000 \\
288,000\end{array}$ & $\begin{array}{l}\text { Do. } \\
\text { Do. }\end{array}$ \\
\hline A-18 & 700 & 51,500 & .26 & .23 & 21. 4 & 14 & .56 & 27.8 & 22 & $\begin{array}{l}80.4 \\
87.8\end{array}$ & $\begin{array}{l}1.790 \\
2.064\end{array}$ & 300,000 & Do. \\
\hline A-8 & 700 & 53,330 & 2. 01 & .15 & 670 & 0.6 & .55 & 1. 2 & 23.5 & 83.6 & 1.808 & 325,000 & Do. \\
\hline A-15 & 900 & 24,000 & 0.01 & .19 & 0.67 & 1,320 & 1.08 & 3,546 & 42 & 84.5 & 1.863 & 154,000 & Do. \\
\hline A-12 & 900 & 26,670 & .06 & .31 & 1. 66 & 800 & 1. 62 & 1,746 & 30.0 & 82.2 & 1. 721 & 149,000 & Do. \\
\hline A-9 & 900 & 32,000 & .11 & .17 & 6.55 & 165 & 1. 25 & 452 & 30.3 & 85.0 & 1. 901 & 213,000 & Do. \\
\hline A-5 & 900 & 37,330 & .35 & .30 & 61 & 9 & 0.85 & 44.5 & 33.5 & 89.5 & 2. 219 & 343,000 & Do. \\
\hline $\begin{array}{l}A-16 \\
A-11\end{array}$ & $\begin{array}{r}900 \\
\end{array}$ & 40,000 & .51 & .29 & 200 & $\begin{array}{r}3.2 \\
2.00\end{array}$ & .93 & $\begin{array}{r}7.5 \\
853\end{array}$ & 24.5 & 82.8 & 1. 761 & 232,000 & $\begin{array}{l}\text { Do. } \\
\text { Test stopped in third }\end{array}$ \\
\hline $\mathrm{A}-11$ & 1,200 & 2,665 & .15 & 1.2 & 1. 24 & 2,100 & 3.8 & 4,853 & a 8.5 & b 7.5 & & & $\begin{array}{l}\text { Test stopped in third } \\
\text { stage. }\end{array}$ \\
\hline$A-6$ & 1,200 & 4,010 & .40 & 1. 75 & 7.9 & 500 & 5.7 & 3,825 & 74.5 & 78.8 & 1. 554 & 19,000 & $\begin{array}{l}\text { Tested to complete frac- } \\
\text { ture. }\end{array}$ \\
\hline $\begin{array}{l}\mathrm{A}-7 \\
\mathrm{~A}-14\end{array}$ & $\begin{array}{l}1,200 \\
1,200\end{array}$ & $\begin{array}{l}6,670 \\
9,330\end{array}$ & $\begin{array}{l}1.88 \\
6.72\end{array}$ & $\begin{array}{l}4.15 \\
7.6\end{array}$ & $\begin{array}{l}72.6 \\
632\end{array}$ & $\begin{array}{l}58.5 \\
21.2\end{array}$ & $\begin{array}{r}8.4 \\
21.0\end{array}$ & $\begin{array}{l}86 \\
28,3\end{array}$ & $\begin{array}{l}97.3 \\
62.5\end{array}$ & $\begin{array}{l}97.6 \\
97.8\end{array}$ & $\begin{array}{l}3.745 \\
3.839\end{array}$ & $\begin{array}{l}281,000 \\
433,000\end{array}$ & $\begin{array}{l}\text { Do. } \\
\text { Do. }\end{array}$ \\
\hline & & & & & & & & & & & & & \\
\hline
\end{tabular}

a These values are for plastic strain as the specimens did not break.

$\mathrm{b}$ These values are for contraction of area as the specimens did not break.

TABLE 2a. Test conditions and results of creep tests on OFHC copper, cold-drawn 40-percent reduction in area

\begin{tabular}{|c|c|c|c|c|c|c|c|c|c|c|c|c|}
\hline \multirow{2}{*}{ Specimen } & \multirow{2}{*}{$\begin{array}{l}\text { Test tem- } \\
\text { perature }\end{array}$} & \multirow{2}{*}{$\begin{array}{l}\text { Creep } \\
\text { stress }\end{array}$} & \multicolumn{2}{|c|}{ Plastic strain } & \multirow{2}{*}{$\begin{array}{l}\text { A verage } \\
\text { creep } \\
\text { rate, } \\
\text { second } \\
\text { stage }\end{array}$} & \multicolumn{2}{|c|}{$\begin{array}{l}\text { Bes inning of third } \\
\text { stage }\end{array}$} & \multicolumn{4}{|c|}{ End of test } & \multirow[b]{2}{*}{ Remarks } \\
\hline & & & $\begin{array}{l}1 \text { hour } \\
\text { after } \\
\text { appli- } \\
\text { cation } \\
\text { of load }\end{array}$ & $\begin{array}{c}\text { Inter- } \\
\text { cept at } \\
\text { zero time }\end{array}$ & & Time & $\begin{array}{l}\text { Plastic } \\
\text { strain }\end{array}$ & Time & $\begin{array}{l}\text { Elonga- } \\
\text { tion }\end{array}$ & $\begin{array}{l}\text { Reduc- } \\
\text { tion of } \\
\text { area }\end{array}$ & $\begin{array}{l}\text { True } \\
\text { strain at } \\
\text { fracture }\end{array}$ & \\
\hline 9. & ${ }^{\circ} \mathrm{F}$ & $\begin{array}{l}l b / \text { in }^{2} \\
29,335\end{array}$ & $\begin{array}{c}\% \\
0.22\end{array}$ & $\begin{array}{l}\% \\
0.38\end{array}$ & $\begin{array}{c}\% / 1,000 h r \\
0.75\end{array}$ & $\begin{array}{r}h r \\
1,160\end{array}$ & $\begin{array}{l}\% \\
1.25\end{array}$ & $\begin{array}{c}h r \\
1,945\end{array}$ & $\begin{array}{l}\% \\
5.5\end{array}$ & $\begin{array}{l}\% \\
9\end{array}$ & $\begin{array}{c}\log _{e}\left(A_{0} / A\right) \\
0.092\end{array}$ & $\begin{array}{l}\text { Tested to complete frac- } \\
\text { ture. }\end{array}$ \\
\hline 12 & $\begin{array}{l}300 \\
300\end{array}$ & $\begin{array}{l}40,000 \\
42,670\end{array}$ & .57 & .34 & $\begin{array}{r}240 \\
2,100\end{array}$ & $\begin{array}{l}1.5 \\
0.05\end{array}$ & .7 & 3.4 & 20 & 79.5 & 1.596 & Do. \\
\hline $14 \ldots$ & 700 & 1,450 & .001 & .11 & ${ }^{2,100} .62$ & 3,400 & 2.2 & $8,450^{\circ}$ & $24^{\circ}$ & 9 & .095 & $\begin{array}{l}\text { Do. } \\
\text { Do. }\end{array}$ \\
\hline $7 \ldots$ & 700 & 2,100 & .07 & .21 & 2.2 & 600 & 1. 52 & 2,505 & 17 & 10.5 & $\begin{array}{l}.090 \\
.109\end{array}$ & Do. \\
\hline $6 \ldots$ & 700 & 2,765 & 01 & .3 & 3 & 410 & 1.5 & 1,306 & 15 & 9.5 & .1 & Do. \\
\hline $21 \ldots$ & 700 & 4,010 & .82 & 1.53 & 11. 6 & 275 & 4. 75 & 575 & 15.5 & 10.5 & .109 & Do. \\
\hline 5 & 700 & 5,330 & 1.52 & 2 & 64 & 80 & 7.1 & 110 & 18.5 & 13 & .139 & Do. \\
\hline $4 \ldots$ & 700 & 10,670 & 11.1 & 7.8 & 3,540 & 1. 75 & 14 & 4 & 365 & 29 & .343 & Do. \\
\hline $20 \ldots$ & 900 & 725 & .015 & .05 & 2. 75 & 960 & 2.7 & 3,146 & 25 & 14.5 & .158 & Do. \\
\hline $8 \ldots$ & 900 & 1,450 & .08 & .17 & 13.3 & 250 & 3.5 & 535 & 13 & 12.5 & .131 & Do. \\
\hline $10 \ldots$ & 900 & 2,100 & .21 & .28 & 50 & 70 & 3.8 & 143 & 17 & 11 & .113 & Do. \\
\hline & 900 & 2,765 & .72 & .7 & 166 & 50 & 9 & 54.5 & 20 & 13.5 & .147 & Do. \\
\hline 16 & 900 & 5,330 & 5.34 & 2.9 & 2,480 & 2.3 & 8.6 & 4. 4 & 27 & 22 & .248 & Do. \\
\hline $18 \ldots$ & 1,200 & 365 & .005 & 1. 2 & 1.4 & 840 & 2.4 & 1,606 & 7.5 & 16 & .173 & Do. \\
\hline 19 & 1,200 & 725 & .11 & 3 & 50.5 & 120 & 6.4 & 214 & 21 & 17.5 & .190 & Do. \\
\hline 13 & 1,200 & 1,450 & 1.25 & 1. 1 & 390 & 20 & 9 & 21 & 16 & 18 & .199 & Do. \\
\hline $17 \ldots \ldots \ldots$ & 1,200 & 2,100 & 4.53 & 2.2 & 2,300 & 2.5 & 6 & 2. 9 & 15 & 25 & .285 & Do. \\
\hline
\end{tabular}


TABLE $2 \mathrm{~b}$. Test conditions and results of creep tests on 70 percent Ni-30 percent $\mathrm{Cu}$, cold-drawn 40 -percent reduction in area

\begin{tabular}{|c|c|c|c|c|c|c|c|c|c|c|c|c|}
\hline \multirow[b]{2}{*}{ Specimen } & \multirow{2}{*}{$\begin{array}{l}\text { Test tem- } \\
\text { perature }\end{array}$} & \multirow{2}{*}{$\begin{array}{l}\text { Creep } \\
\text { stress }\end{array}$} & \multicolumn{2}{|c|}{ Plastic strain } & \multirow{2}{*}{$\begin{array}{l}\text { A verage } \\
\text { creep } \\
\text { rate, } \\
\text { second } \\
\text { stage }\end{array}$} & \multicolumn{2}{|c|}{$\begin{array}{l}\text { Beginning of third } \\
\text { stage }\end{array}$} & \multicolumn{4}{|c|}{ End of test } & \multirow{2}{*}{ Remarks } \\
\hline & & & $\begin{array}{l}1 \text { hour } \\
\text { after } \\
\text { appli- } \\
\text { cation } \\
\text { of load }\end{array}$ & $\begin{array}{c}\text { Inter- } \\
\text { cept at } \\
\text { zero time }\end{array}$ & & Time & $\begin{array}{l}\text { Plastic } \\
\text { strain }\end{array}$ & Time & $\begin{array}{l}\text { Elonga- } \\
\text { tion }\end{array}$ & $\begin{array}{l}\text { Reduc- } \\
\text { tion of } \\
\text { area }\end{array}$ & $\begin{array}{l}\text { True } \\
\text { strain at } \\
\text { fracture }\end{array}$ & \\
\hline 23 & $\stackrel{\circ}{\circ}$ & $\begin{array}{l}\text { lb/in.2 } \\
93,000\end{array}$ & $\begin{array}{r}\% \\
0.12\end{array}$ & $\begin{array}{r}\% \\
0.21\end{array}$ & $\begin{array}{c}\% / 1,000 h r \\
0\end{array}$ & $h r$ & $\%$ & $\begin{array}{r}h r \\
1,651\end{array}$ & $\begin{array}{c}\% \\
\text { a } 0.21\end{array}$ & $\begin{array}{r}\% \\
\text { в } 0.2\end{array}$ & $\log _{e}\left(A_{0} / A\right)$ & $\begin{array}{l}\text { Test stopped in second } \\
\text { stage. }\end{array}$ \\
\hline 24 & $\begin{array}{l}300 \\
300\end{array}$ & $\begin{array}{l}93,800 \\
94,300\end{array}$ & $\begin{array}{l}.49 \\
.54\end{array}$ & $\begin{array}{l}.56 \\
.62\end{array}$ & $\begin{array}{l}0 \\
0\end{array}$ & & & 1,200 & $\begin{array}{l}\text { a } 56 \\
\text { a. } 62\end{array}$ & $\begin{array}{l}\text { b. } 5 \\
\text { b. } 6\end{array}$ & & $\begin{array}{l}\text { Do. } \\
\text { Do. }\end{array}$ \\
\hline $20 \mathrm{~A}$ & 300 & 94,500 & & .02 & 940 & 0.19 & 0.6 & & & 76 & 1. 431 & Tested to complete frac- \\
\hline $\begin{array}{l}14 \ldots \\
21 \mathrm{~B} \\
13 \\
12 \\
17 \\
22\end{array}$ & $\begin{array}{l}700 \\
700 \\
700 \\
700 \\
700 \\
700\end{array}$ & $\begin{array}{l}69,330 \\
72,000 \\
74,670 \\
80,000 \\
82,670 \\
84,000\end{array}$ & $\begin{array}{r}.06 \\
.46 \\
.29 \\
1.16 \\
3.15\end{array}$ & $\begin{array}{l}1.8 \\
2.5 \\
.50 \\
1.08 \\
3.03\end{array}$ & $\begin{array}{c}2.78 \\
11.52 \\
76 \\
118 \\
10,000\end{array}$ & $\begin{array}{r}7,300 \\
2,300 \\
265 \\
3 \\
2.1\end{array}$ & $\begin{array}{l}7.5 \\
7.52 \\
3.45 \\
1.29 \\
3.28\end{array}$ & $\begin{array}{c}10,199 \\
3,097 \\
602 \\
35 \\
4.8 \\
0.2\end{array}$ & $\begin{array}{l}21 \\
20 \\
30 \\
24 \\
20 \\
17\end{array}$ & $\begin{array}{l}48 \\
54 \\
62.5 \\
74 \\
71 \\
72.5\end{array}$ & $\begin{array}{r}.653 \\
.780 \\
.979 \\
1.354 \\
1.230 \\
1.296\end{array}$ & $\begin{array}{l}\text { Do. } \\
\text { Do. } \\
\text { Do. } \\
\text { Do. } \\
\text { Do. } \\
\text { Do. }\end{array}$ \\
\hline 28 & 900 & $\begin{array}{l}21,330 \\
21,300\end{array}$ & .13 & .32 & .90 & 1,400 & 1.6 & 13,839 & 62 & 54.5 & .790 & Do. \\
\hline $\begin{array}{l}30 \\
29 \\
29\end{array}$ & 900 & 24,000 & .08 & .40 & 1.4 & 420 & 1.0 & 2,415 & ${ }^{2} 6.18$ & b 5.8 & & Test stopped in third stage. \\
\hline 29 & $\begin{array}{l}900 \\
900\end{array}$ & $\begin{array}{l}24,000 \\
26,670\end{array}$ & $\begin{array}{l}.17 \\
14\end{array}$ & .50 & 2.0 & 1,000 & 2.5 & $\begin{array}{l}4,875 \\
4,255\end{array}$ & 55 & $\begin{array}{l}59.5 \\
61\end{array}$ & $\begin{array}{l}.901 \\
.944\end{array}$ & $\begin{array}{l}\text { Tested to complete fractu } \\
\text { Do. }\end{array}$ \\
\hline & 900 & $\begin{array}{l}20,0 \\
32,06\end{array}$ & .10 & & & & & 3,570 & 37 & 45 & .596 & Do. \\
\hline 15 & 90 & 37,330 & .23 & .50 & 12.6 & 100 & 1.75 & 507 & & 55.5 & .806 & Do. \\
\hline 10 & & & 51 & 1.8 & 24 & 200 & 6.6 & 367 & 31 & 52.5 & .740 & Do. \\
\hline 7 & 900 & 48,00 & .78 & $\begin{array}{l}1.0 \\
0\end{array}$ & 52 & & 7.5 & 185 & 29 & 53 & .751 & Do. \\
\hline 11. & 900 & 53,3 & 1. 0 & .75 & 260 & 13.4 & 4.2 & 29 & 31 & 52.5 & .740 & \\
\hline $20 \mathrm{~B}$ & 900 & 58,670 & 2. 18 & 1.1 & 1,040 & 3.3 & 4.6 & 7.5 & 25 & 59 & .885 & $\begin{array}{l}\text { Do. } \\
\text { Test }\end{array}$ \\
\hline & 1,200 & 2,100 & .04 & .16 & 0 & & & 1,513 & a. 16 & & & $\begin{array}{l}\text { Test stopped in secona } \\
\text { stage. }\end{array}$ \\
\hline $\begin{array}{l}8 \\
27\end{array}$ & 1,200 & 2,665 & .02 & .68 & .51 & 2300 & 12 & $4310^{-1}$ & 31 & 21.5 & .239 & $\begin{array}{l}\text { Do. } \\
\text { Tested to complete frac- }\end{array}$ \\
\hline & 1,200 & 4,010 & .00 & 1.5 & 4.6 & 2,800 & 12 & 4,310 & & 2.0 & .200 & ture. \\
\hline $\begin{array}{l}9 . \\
4\end{array}$ & 1,200 & & & & & & & 2,001 & 31 & $\begin{array}{r}25.5 \\
28.5\end{array}$ & .293 & $\begin{array}{l}\text { Do. } \\
\text { Do. }\end{array}$ \\
\hline & $\begin{array}{l}1,200 \\
1,200\end{array}$ & $\begin{array}{l}6,670 \\
9,330\end{array}$ & $\begin{array}{l}.08 \\
.31\end{array}$ & $\begin{array}{l}.05 \\
.4\end{array}$ & $\begin{array}{l}12.5 \\
43.5\end{array}$ & $\begin{array}{l}115 \\
110\end{array}$ & $\begin{array}{r}1.5 \\
5.2\end{array}$ & $\begin{array}{l}960 \\
401\end{array}$ & $\begin{array}{l}50 \\
42\end{array}$ & 32 & .385 & Do. \\
\hline & 1,200 & 16,000 & 3.82 & 2.9 & 1,040 & 10.2 & 13.5 & 18 & 47 & 44 & .579 & Do. \\
\hline
\end{tabular}

a These values are for plastic strain as specimens did not break.

b These values are for contraction of area as specimens did not break.

TABLE 2c. Test conditions and results of creep tests on 30 percent $\mathrm{Ni- \gamma O}$ percent $\mathrm{Cu}$, cold-drawn 40 -percent reduction in area

\begin{tabular}{|c|c|c|c|c|c|c|c|c|c|c|c|c|}
\hline \multirow{2}{*}{ Specimen } & \multirow{2}{*}{$\begin{array}{l}\text { Test tem- } \\
\text { perature }\end{array}$} & \multirow{2}{*}{$\begin{array}{l}\text { Creep } \\
\text { stress }\end{array}$} & \multicolumn{2}{|c|}{ Plastic strain } & \multirow{2}{*}{$\begin{array}{l}\text { A verage } \\
\text { creep } \\
\text { rate, } \\
\text { second } \\
\text { stage }\end{array}$} & \multicolumn{2}{|c|}{$\begin{array}{l}\text { Beginning of third } \\
\text { stage }\end{array}$} & \multicolumn{4}{|c|}{ End of test } & \multirow{2}{*}{ Remarks } \\
\hline & & & $\begin{array}{l}1 \text { hour } \\
\text { after } \\
\text { appli- } \\
\text { cation } \\
\text { of load }\end{array}$ & $\begin{array}{c}\text { Inter- } \\
\text { cept at } \\
\text { zero time }\end{array}$ & & Time & $\begin{array}{l}\text { Plastic } \\
\text { strain }\end{array}$ & Time & $\begin{array}{l}\text { Elonga- } \\
\text { tion }\end{array}$ & $\begin{array}{l}\text { Reduc- } \\
\text { tion of } \\
\text { area }\end{array}$ & $\begin{array}{l}\text { True } \\
\text { strain at } \\
\text { fracture }\end{array}$ & \\
\hline 14 & $\begin{array}{l}\circ F \\
{ }^{\circ} F\end{array}$ & $\begin{array}{l}\text { lb/in. }{ }^{2} \\
72,000\end{array}$ & $\begin{array}{c}\% \\
0.23\end{array}$ & $\begin{array}{l}\% \\
0.28\end{array}$ & $\begin{array}{c}\% / 1,000 \mathrm{hr} \\
0\end{array}$ & $h r$ & $\%$ & $\begin{array}{r}h r \\
2,011\end{array}$ & $\begin{array}{c}\% \\
\mathrm{a} 0.28\end{array}$ & $\begin{array}{l}\% \\
\mathrm{~b} \\
0.3\end{array}$ & $\log _{e}\left(A_{0} / A\right)$ & Test stopped in second \\
\hline $\begin{array}{l}16 \\
18\end{array}$ & $\begin{array}{l}300 \\
300\end{array}$ & $\begin{array}{l}73,100 \\
75,000\end{array}$ & $\begin{array}{l}.33 \\
.40\end{array}$ & $\begin{array}{l}.40 \\
.30\end{array}$ & $\begin{array}{r}0 \\
115\end{array}$ & 1.1 & 0.42 & $\begin{array}{l}1,652 \\
1.5\end{array}$ & $\begin{array}{l}\mathrm{a} \\
15\end{array}$ & $\begin{array}{l}\text { b. } \\
71\end{array}$ & 1. 241 & $\begin{array}{l}\text { Do. } \\
\text { Tested to complete frac- } \\
\text { ture }\end{array}$ \\
\hline $13 \ldots$ & 700 & 42,670 & 0.0 & .27 & 0.33 & & & 8,490 & a 3 & b 3 & & $\begin{array}{l}\text { ture. } \\
\text { Test stopped in second } \\
\text { stage. }\end{array}$ \\
\hline 15 & 700 & 51,500 & .16 & .50 & 1.7 & 690 & 1.65 & 1,550 & 8 & 31.5 & 0.375 & $\begin{array}{l}\text { Tested to complete frac- } \\
\text { ture. }\end{array}$ \\
\hline $\begin{array}{l}20 \ldots \\
19\end{array}$ & $\begin{array}{l}700 \\
700\end{array}$ & 53,330 & .31 & $\begin{array}{l}.65 \\
60\end{array}$ & $\begin{aligned} 22.3 & \\
100 & \end{aligned}$ & 85 & $\begin{array}{l}2.4 \\
1.95\end{array}$ & $\begin{array}{r}165 \\
28\end{array}$ & 16 & 33 & .399 & Do. \\
\hline $\begin{array}{l}19 \\
21\end{array}$ & 700 & $\begin{array}{l}56,030 \\
58,670\end{array}$ & 1.2 & $\begin{array}{l}.00 \\
1.04\end{array}$ & $\begin{array}{l}100 \\
160\end{array}$ & $\begin{array}{r}10.0 \\
5.5\end{array}$ & $\begin{array}{l}1.95 \\
1.92\end{array}$ & $\begin{array}{l}28 \\
10\end{array}$ & $\begin{array}{l}15 \\
17\end{array}$ & $\begin{array}{l}45.5 \\
52.5\end{array}$ & $\begin{array}{r}.602 \\
.746\end{array}$ & $\begin{array}{l}\text { Do. } \\
\text { Do. }\end{array}$ \\
\hline 17. & 900 & 16,000 & 0.05 & 0.32 & 0.39 & 3,250 & 1.6 & 14,044 & 46 & 36 & .447 & Do. \\
\hline 10 & 900 & 21,330 & .11 & .45 & 1.5 & 1,550 & 2.75 & 4,190 & 23 & 31.5 & .375 & Do. \\
\hline & 900 & 26,670 & .28 & .55 & 11.1 & 275 & 3.6 & 710 & 35 & & .547 & Do. \\
\hline & 900 & 32,000 & .33 & 35 & 33.3 & 70 & 2. 7 & 192 & 21 & 31.5 & .375 & Do. \\
\hline & 900 & 37,330 & .46 & .29 & 180 & 4. 5 & 1.1 & 20 & 15 & & .292 & Do. \\
\hline & 1,200 & 1,450 & 02 & .40 & 2. 65 & 1,700 & 4.9 & 5,002 & 28.5 & 25 & .287 & Do. \\
\hline & 1,200 & 2,665 & .02 & .10 & 7.5 & 240 & 1.9 & 1,032 & 16 & 15 & .165 & Do. \\
\hline & $\begin{array}{l}1,200 \\
1,200\end{array}$ & 4. 010 & .05 & $\begin{array}{l}.10 \\
.10\end{array}$ & $\begin{array}{c}26.4 \\
240\end{array}$ & $\begin{array}{c}75 \\
1.4\end{array}$ & $\begin{array}{l}2.1 \\
0.43\end{array}$ & $\begin{array}{l}355 \\
47.5\end{array}$ & $\begin{array}{l}31 \\
36\end{array}$ & $\begin{array}{l}21.5 \\
28\end{array}$ & $\begin{array}{l}.240 \\
.328\end{array}$ & $\begin{array}{l}\text { Do. } \\
\text { Do. }\end{array}$ \\
\hline & 1,200 & 6,670 & .36 & .10 & & & & 47.5 & & & & \\
\hline
\end{tabular}

a These values are for plastic strain as specimens did not break.

b These values are for contraction of area as specimens did not break. 
perature with different stresses [9]. The creep curves obtained for the metals used in this investigation were essentially similar when the comparisons were made at equal test temperature - recrystallization temperature ratio values. ${ }^{2}$ The general shape of the creep curves are illustrated by the log strain-log time data in figure 1 for the 30 percent Ni-70 percent $\mathrm{Cu}$ alloy specimens. The general trend of the curves, except for the data at $300^{\circ} \mathrm{F}$, is a positive contour; $i_{x}$ e, an increase in slope of the log-log curves with increase in time; however, linear relations were sometimes observed over limited ranges during the second stage of creep.

In general, this linearity was more apparent at the lower stresses at 700 and 900 than at 300 or $1,700{ }^{\circ} \mathrm{F}$. The ranges of strain, over which a linear relation exists, depends on the strain on loading, the extent of the first stage of creep and the strain at the beginning of the third stage.

Strain-time curves for the cold-drawn specimens of nickel and the nickel alloys tested under identical conditions at 700,900 , and $1,200^{\circ} \mathrm{F}$ are shown in figures 2 to 5 , inclusive. Tests for the copper could

2 Approximate recrystallization values for the cold-drawn metals used in this investigation are: $\mathrm{Cu}, 350^{\circ} ; \mathrm{Ni}, 1,100^{\circ} ; 70$ percent $\mathrm{Ni}-30$ percent $\mathrm{Cu}, 1,100^{\circ} ; 30$ investigation are: $\mathrm{Cu}, 3500^{\circ} \mathrm{Ni}, 1,100 ; 70$ percent $\mathrm{Ni}-30$
percent Ni-70 percent $\mathrm{Cu}, 1,050^{\circ} \mathrm{F}$ ( $1 \mathrm{hr}$ at temperature). not be made at the stress levels shown in these figures as its creep resistance ${ }^{3}$ was too low. The creep stresses used on the 70 percent Ni-30 percent $\mathrm{Cu}$ alloy at $700{ }^{\circ} \mathrm{F}$ were too high to compare with the other metals under equal test conditions. The resistance of creep of the 30 percent $\mathrm{Ni}-70$ percent $\mathrm{Cu}$ alloy was greater than that of the nickel at $700{ }^{\circ} \mathrm{F}$ (figs. 2 and 3 ). The magnitude of the increase was greater for the higher stresses. The creep resistance at 900 (fig. 4) and $1,200{ }^{\circ} \mathrm{F}$ (fig. 5) of the nickel is generally intermediate between the 70 percent nickel alloy and the 30 percent nickel alloy. Apparently the solute atoms which act as barriers to the motion of dislocations are less effective as the temperature is raised. Prior cold-drawing tends to decrease the temperature range at which strengthening due to alloying is effective [8]. Furthermore, as indicated by the microstructures obtained after fracture (fig. 21 ), some recrystallization occurred in some of the 30 percent Ni-70 percent $\mathrm{Cu}$ specimens tested at $900^{\circ} \mathrm{F}$. This phenomenon would tend to cause a decrease in the creep resistance of the alloy below that of the unrecrystallized nickel tested under identical conditions.

${ }^{3}$ When the test conditions are identical, the more creep-resistant metal may be defined as the one having the smaller strain at a given time.
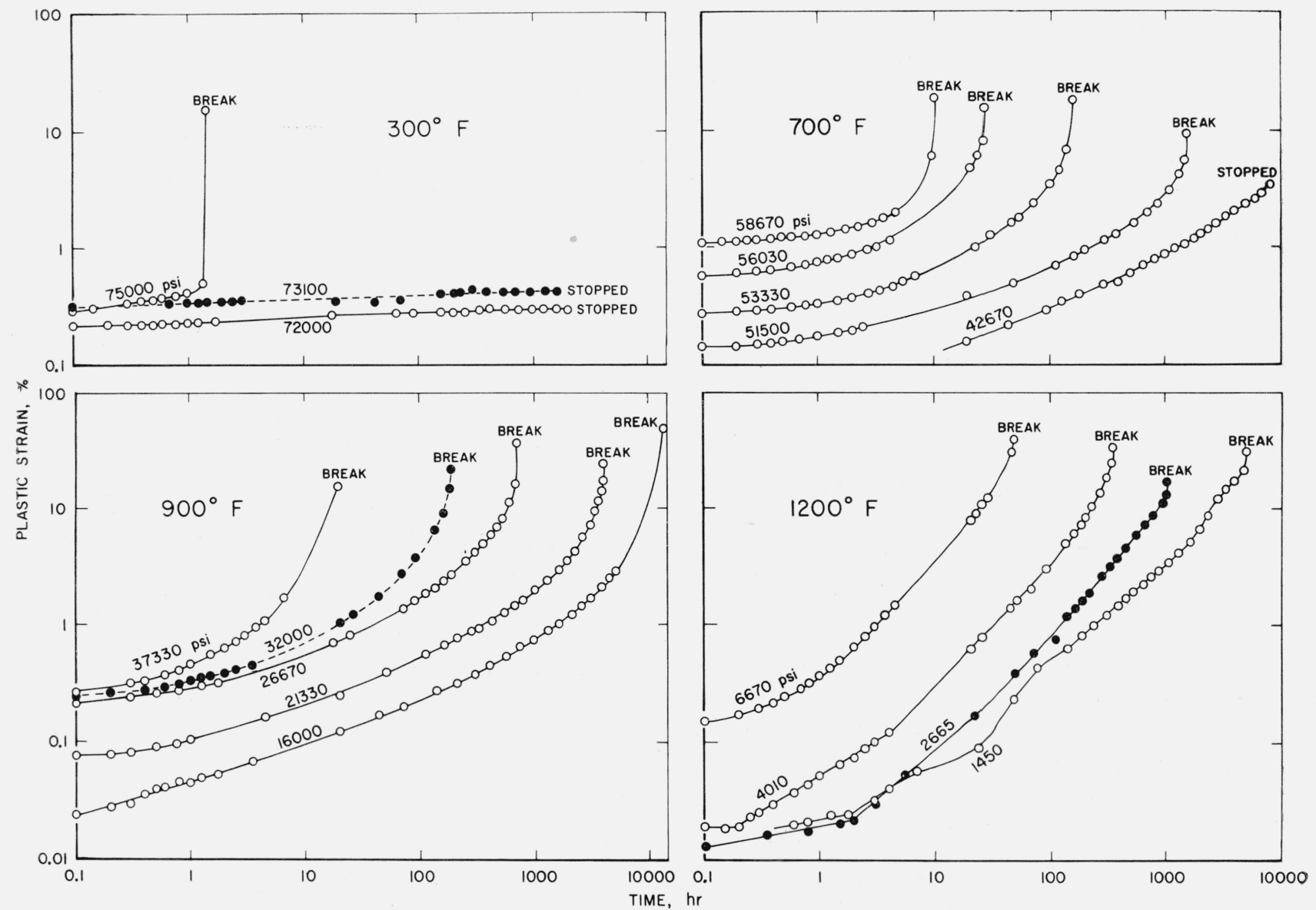

Figure 1. Strain-time curves for the cold-drawn $30 \% \mathrm{Ni-} \% 0 \% \mathrm{Cu}$ specimens tested in creep. 


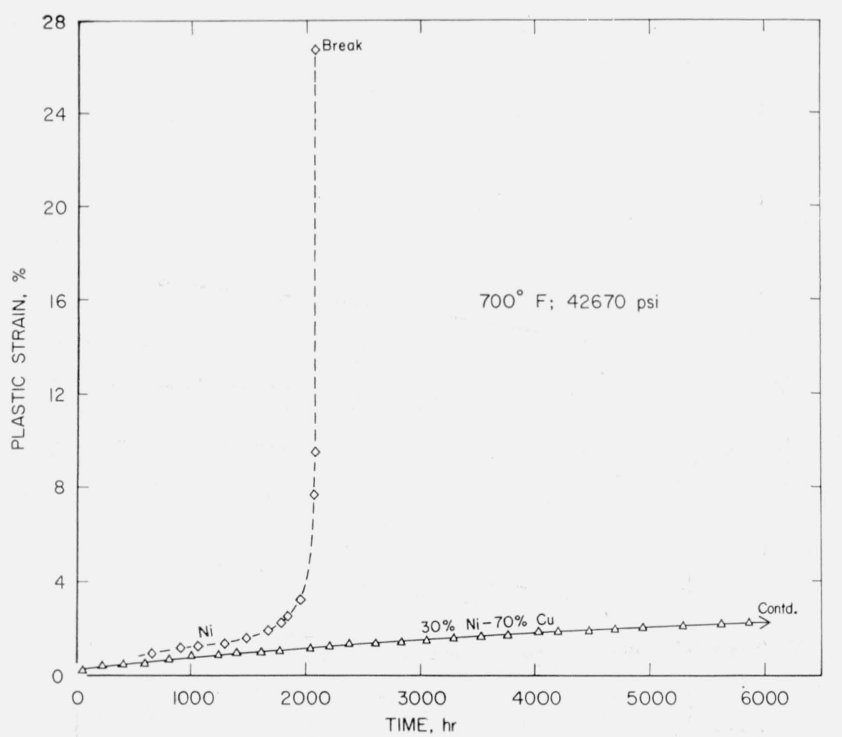

Figure 2. Strain-time relations of cold-drawn specimens tested at $700{ }^{\circ} \mathrm{F}$ with a stress of $42,6 \% 0 \mathrm{psi}$.

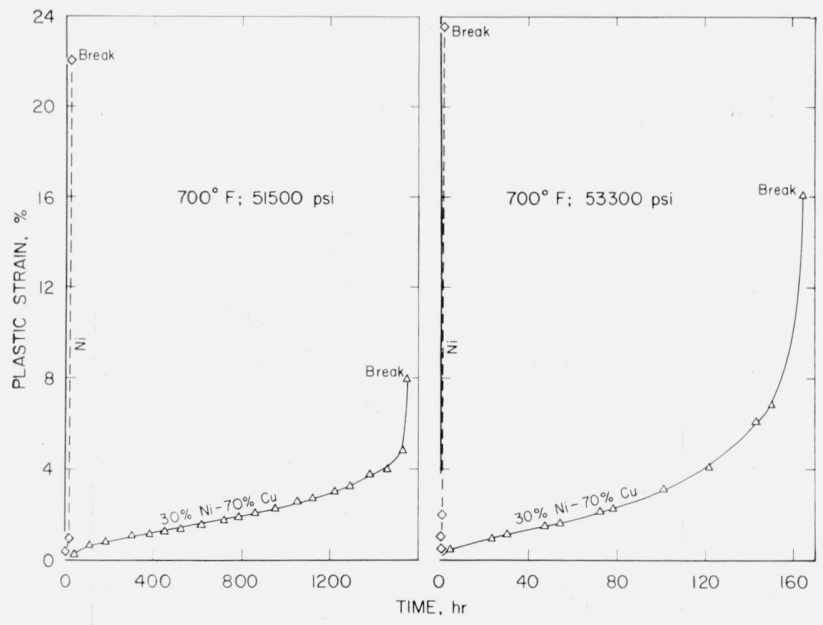

Figure 3. Strain. time relations of cold-drawn specimens tested at $700{ }^{\circ} \mathrm{F}$ with different stresses.

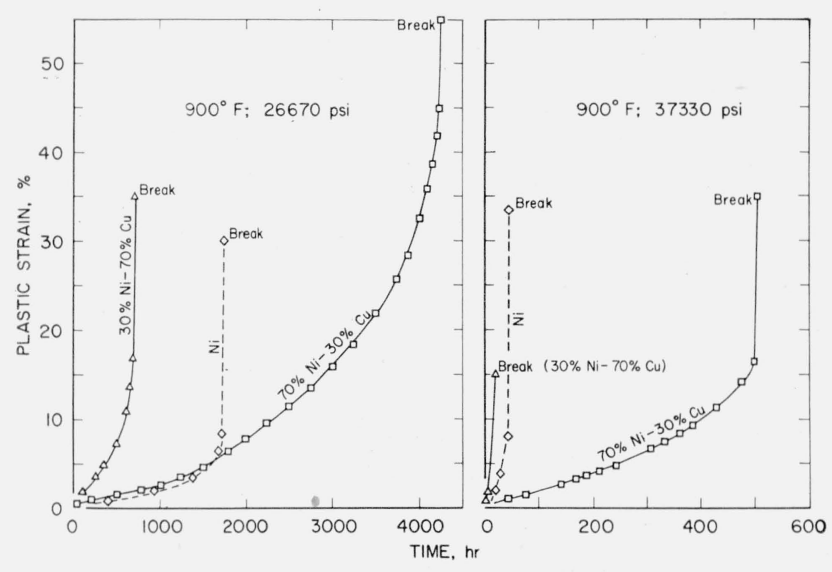

FIGURE 4. Strain-time relations of cold-drawn specimens tested at $900^{\circ} \mathrm{F}$ with different stresses.

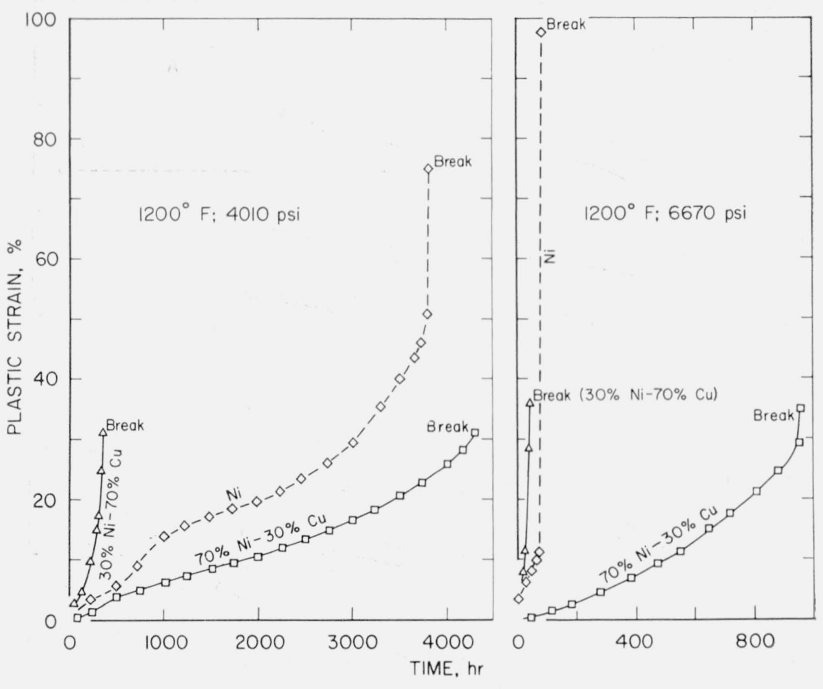

Figure 5. Strain-time relations of cold-drawn specimens tested at 1,200 ${ }^{\circ} \mathrm{F}$ with different stresses.

\subsection{Relations of Temperature, Stress, and Composition to Second Stage Creep Rate}

During the first stage of creep, the creep rate decreases as the test time increases. Eventually, the creep rate appears to become approximately constant over a period of time, the extent of which depends on the test conditions. This constant rate, which is described as the second stage creep rate, has been used as a strength index for evaluating the properties of different materials at constant or differing test conditions. Furthermore, this constancy of rate has become the basis for much theoretical discussion as the second stage is sometimes considered to be the range in which there is a balance between strain hardening and recovery of metal crystals. Some of the formulas derived from theoretical considerations indicate that either a linear or a power relation exists between the applied stress and second stage creep rate. Others indicate a linear relation between creep rate and the hyperbolic sine of the stress [12]. It has also been postulated that a single curve might describe stress-creep rate parameter relations over a wide range of temperatures and stresses [13].

The degree of success in the application of the formulas to data obtained in creep tests depends on such factors as the models used, the initial condition of the metals, the homologous temperature, the creep stress-tensile strength ratio, the reactions taking place during testing, and the ductility.

The interrelations of stress, second stage creep rate, and temperature, as influenced by composition and cold-drawing, are shown, for the metals used in the present investigation, in figures 6 to 12 , inclusive.

The relations of creep stress, and of the creep stress-tensile strength ratio to the second stage creep rate of the annealed and cold-drawn 30 percent Ni-70 percent $\mathrm{Cu}$ alloy specimens, are shown in figure 6. At each temperature, the shape of the 


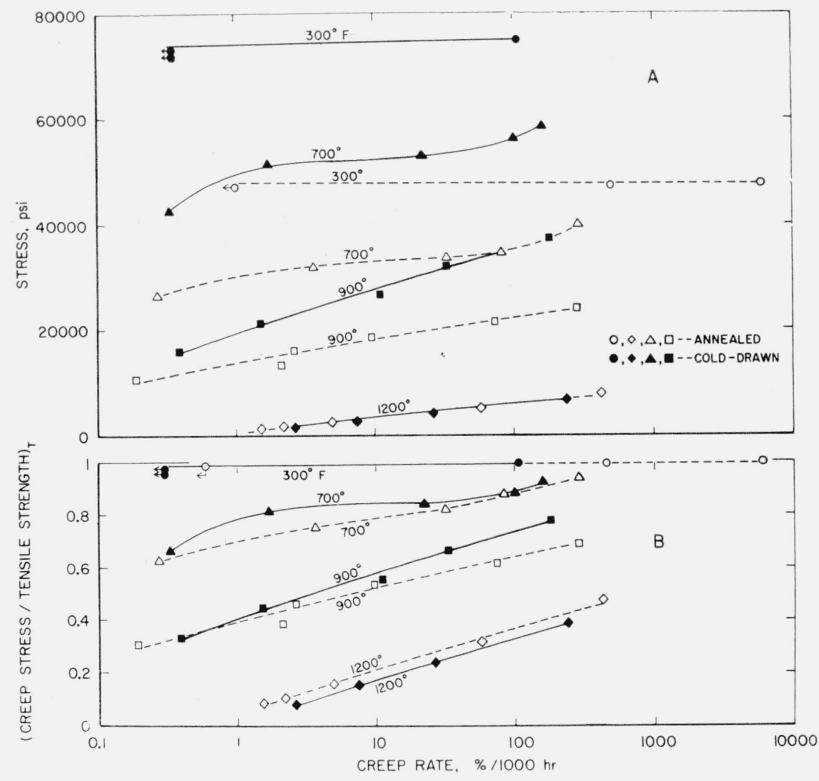

Figure 6. Effect of cold-drawing on (A) the stress-creep rate relations and on $(B)$ the creep stress-tensile strength ratio-creep rate relations for $30 \% \mathrm{Ni-}-70 \% \mathrm{Cu}$ specimens.

curves for each condition of the metal is similar (fig. 6A); however, at different temperatures the curves are dissimilar. At 300,700 , and $900{ }^{\circ} \mathrm{F}$, the stress necessary to produce equal creep rates was increased by cold-drawing. The difference decreased with increase in temperature, and at $1,200^{\circ} \mathrm{F}$ there was a coincidence of the curves for the annealed and cold-drawn metal. This is due, in part, to the fact that $1,200^{\circ} \mathrm{F}$ is above the recrystallization temperature of the metal.

Attempts were made to ascertain whether creep data could be calculated from the results of short time tensile tests. Accordingly, the creep stresstensile strength ratios at the different temperatures were determined and plotted as a function of the second stage creep rate for the 30 percent $\mathrm{Ni}-70$ percent $\mathrm{Cu}$ alloy (fig. $6 \mathrm{~B}$ ). As the values of tensile strength [7] are those obtained at the respective temperatures, it is apparent that the creep stresstensile strength ratio to produce equal creep rates decreases as the temperature is increased. However, the decrease in values is less at the fast creep rates than at the slow rates. Cold-drawing the metal appears to increase the ratio slightly at 700 and $900^{\circ} \mathrm{F}$ whereas the reverse is true at $1,200^{\circ} \mathrm{F}$. The magnitude of the increase at $900{ }^{\circ} \mathrm{F}$ was significantly less than that previously shown for the nickel [9]. It is obvious from these results that no simple correlation exists between short-time tensile test data and creep data.

The effect of stress on the second stage creep rate of the cold-drawn metals is shown in figures 7 and 8 . The curves for the nickel and the 30 percent $\mathrm{Ni}$ 70 percent $\mathrm{Cu}$ alloy are usually intermediate between the high values for the 70 percent $\mathrm{Ni}-30$ percent $\mathrm{Cu}$ alloy and the low values for the copper. At $700{ }^{\circ} \mathrm{F}$ the stress necessary to produce equal creep

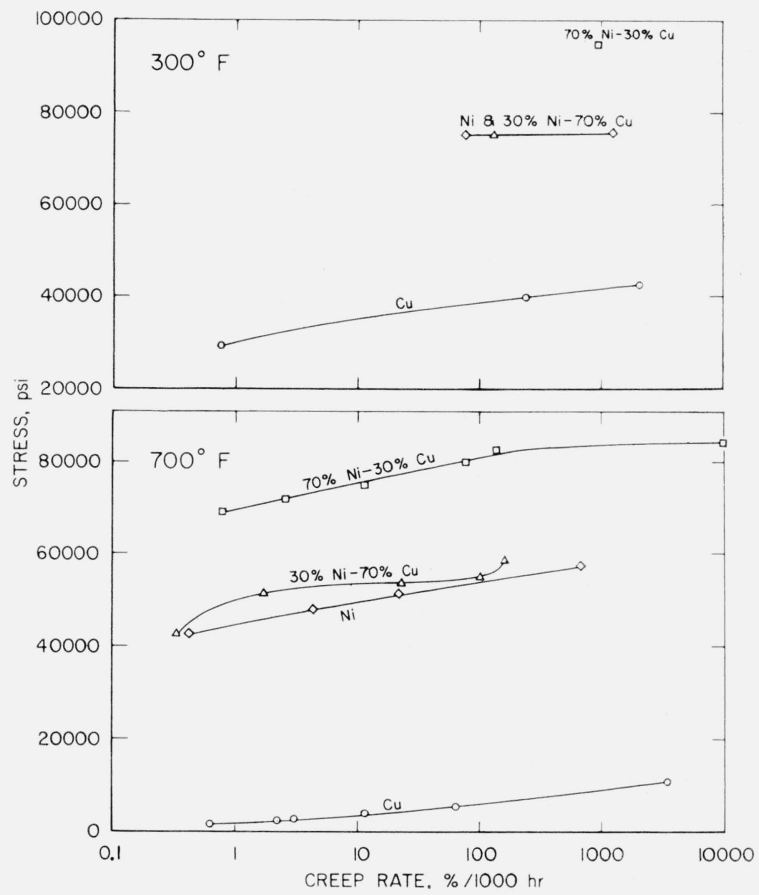

Figure 7. Influence of stress on the average creep rate during the second stage at 300 and $700{ }^{\circ} \mathrm{F}$.

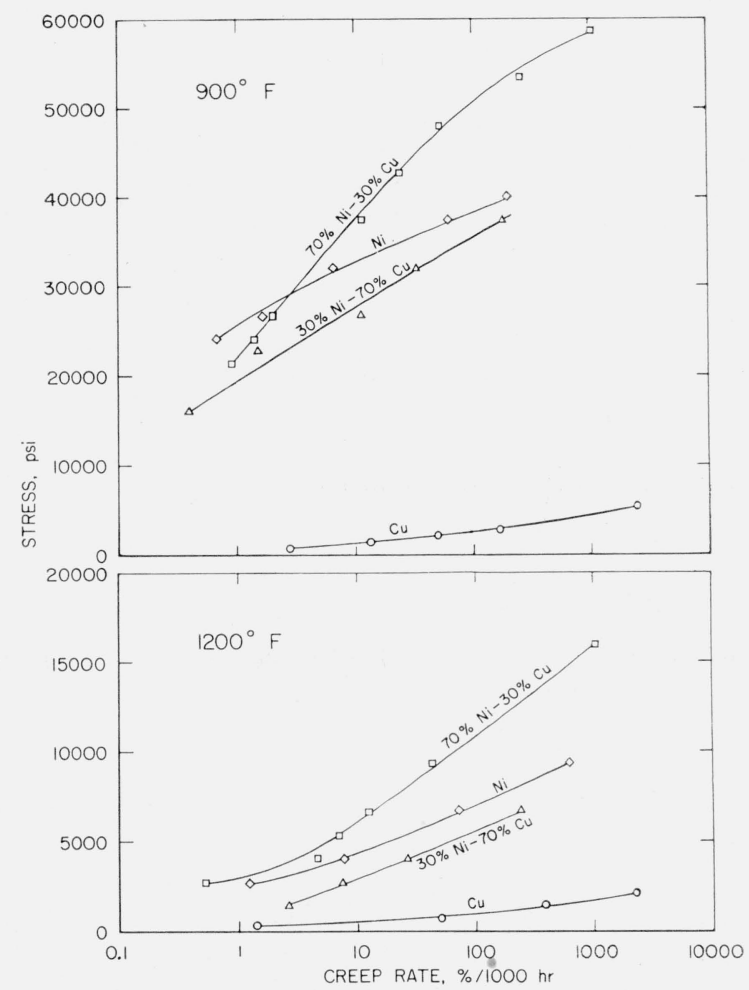

FIGURE 8. Influence of stress on the average creep rate during the second stage at 900 and $1,200{ }^{\circ} \mathrm{F}$. 
rates was slightly greater for the 30 percent $\mathrm{Ni}$ 70 percent $\mathrm{Cu}$ alloy than for the nickel, whereas, at 900 and $1,200^{\circ} \mathrm{F}$ the reverse was observed.

The relation of creep stress-tensile strength ratio to the second stage creep rate of the cold-drawn metals indicated that, at all the temperatures used, this ratio was lowest for the copper. Although the ratios for the alloys at 900 and $1,200{ }^{\circ} \mathrm{F}$ appeared to be intermediate between the high values of the nickel and low values of the copper, they were significantly different at different creep rates. Furthermore, the values were more closely grouped at 1,200 than at $900{ }^{\circ} \mathrm{F}$.

The relation between stress and temperature, to produce creep rates of 1 percent and 100 percent per $1,000 \mathrm{hr}$ on the annealed and cold-drawn 30 percent Ni-70 percent $\mathrm{Cu}$ specimens, is shown in figure 9.A. Strengthening due to cold-drawing is most pronounced at $300{ }^{\circ} \mathrm{F}$ and becomes less pronounced as the temperature is increased. At $1,200{ }^{\circ} \mathrm{F}$, the values for the two conditions are effectively the same. Although the stress increase necessary to produce creep rates of 1 percent and 100 percent per $1,000 \mathrm{hr}$ is small at $300^{\circ} \mathrm{F}$, appreciable increases are required at the higher temperatures. The spread in stress values, to produce different creep rates is greater at 900 than at $1,200{ }^{\circ} \mathrm{F}$ even though the percentage differences at $1,200{ }^{\circ} \mathrm{F}$ are greater.

When log stress-log creep rate values (not shown) for specimens are plotted, a linear relation can often result. The slope of the line $\Delta \log$ stress/ $\Delta J_{0}$ creep rate, at each temperature is designated "rate sensitivity" [14]. Generally, this value increases with increase in temperature as shown by the data for 30 percent $\mathrm{Ni}-70$ percent $\mathrm{Cu}$ alloy specimens in figure $9 \mathrm{~B}$. Cold-drawing the metal appeared to increase the rate-sensitivity at $900^{\circ} \mathrm{F}$. In contrast, cold-drawing the nickel specimens caused a decrease in this property [9]. The relation of composition of the specimens to the rate sensitivity is shown in figure 10 . With the exception of one value for the copper at $1,200^{\circ} \mathrm{F}$, the values for the copper are the highest. The rate sensitivity of the 30 percent $\mathrm{Cu}$ alloy was greater than that of the nickel. Prior cold-drawing appeared to cause an increase in some of the rate-sensitivity values and a decrease in others. This behavior indicates that no smooth relation exists between rate sensitivity and chemical composition.

The relation of composition to the stress necessary to produce equal creep rates at various temperatures of the cold-drawn metals is shown in figure 11. The slopes of the line segments indicate that the greatest increase in stress of the alloys above that of the base metals is obtained at $700^{\circ} \mathrm{F}$ while the least is at $1,200{ }^{\circ} \mathrm{F}$. The latter observation is due to the fact that this is above the recrystallization temperature of all the metals tested. It should also be observed that the slopes of the stresscomposition line segments are also different at different creep rates.

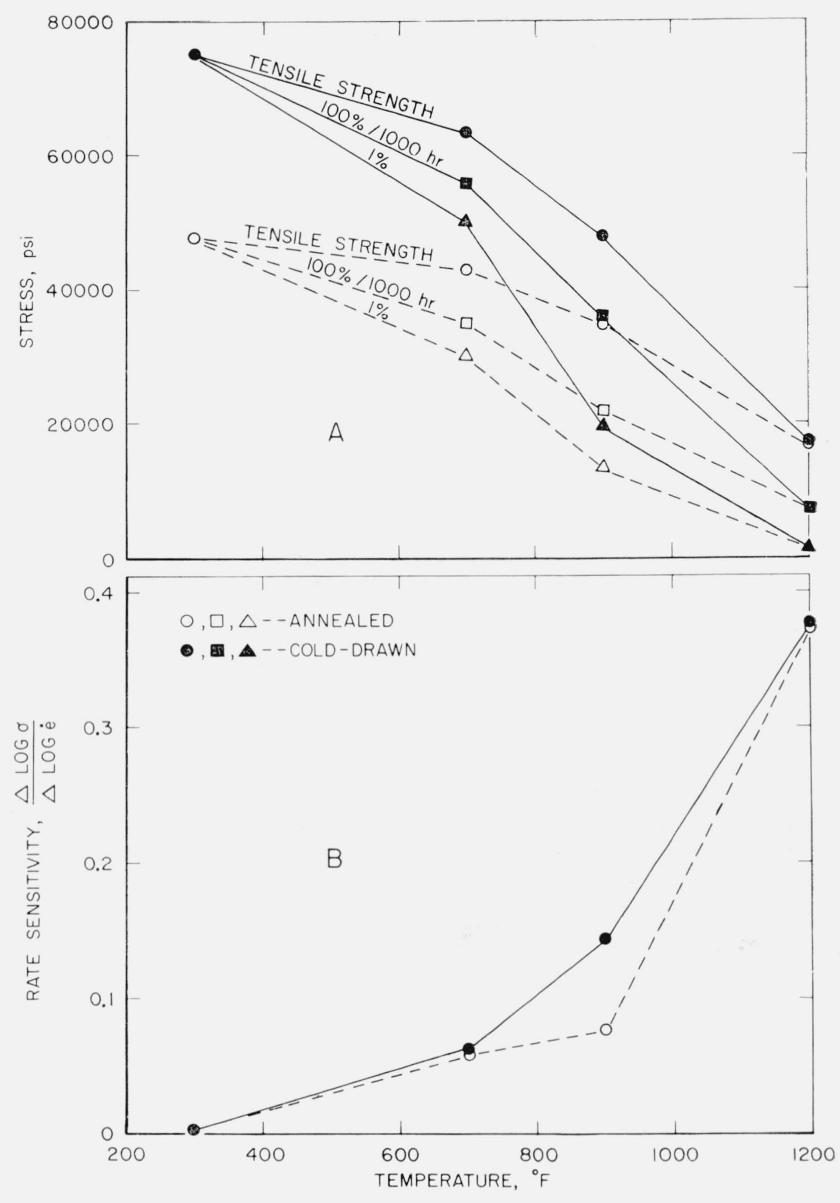

FIGURE 9. Effect of temperature $(A)$ on the tensile strength and the stress to produce different second stage crecp rates and $(B)$ on the rate sensitivity of the annealed and cold-drawn $30 \%$ $\mathrm{Ni}-70 \% \mathrm{Cu}$ specimens.

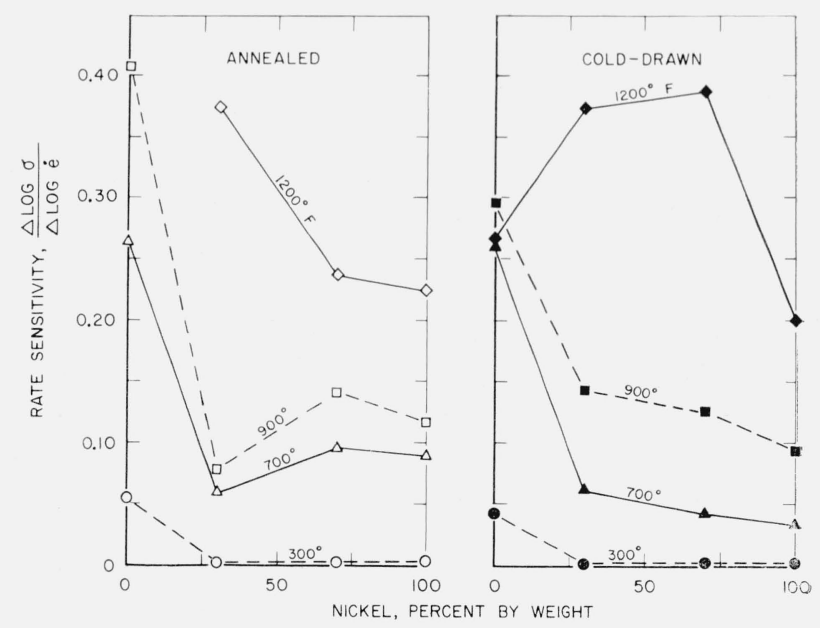

FIGURE 10. Variation of rate sensitivity with nickel content of the annealed and cold-drawn specimens at different temperatures.

( $\sigma$ is the applied creep stress and $\dot{e}$ is the corresponding second stage creep rate.) 


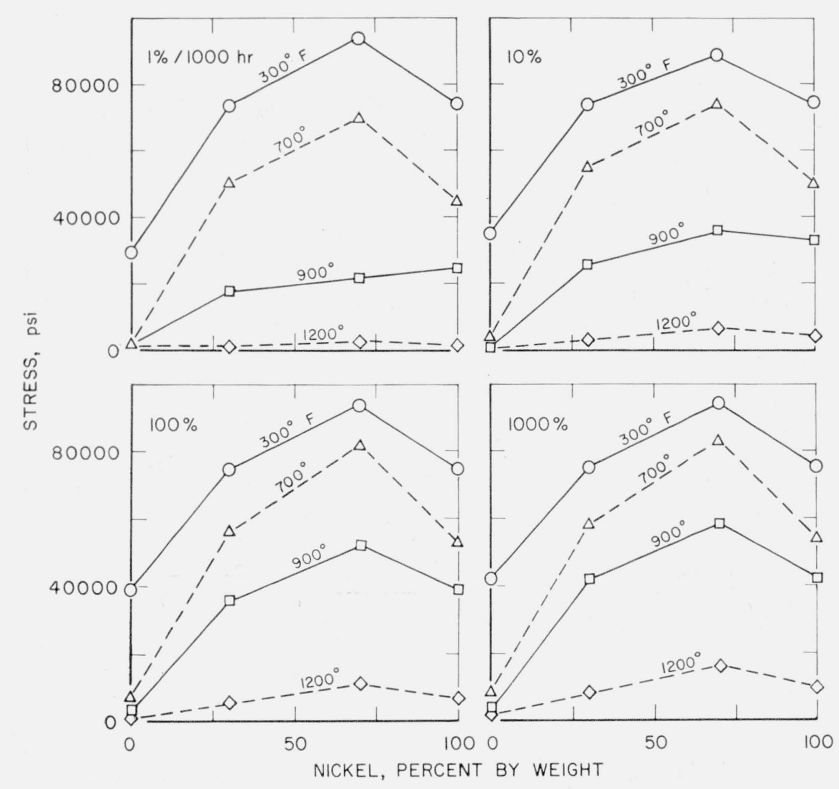

Figure 11. Variation of stress with nickel content to produce equal second stage creep rates at different temperatures of the cold-drawn metals.

\subsection{Relations Between Test Conditions and Fracture Time}

The relations of stress and second stage creep rate to fracture time, as influenced by temperature,
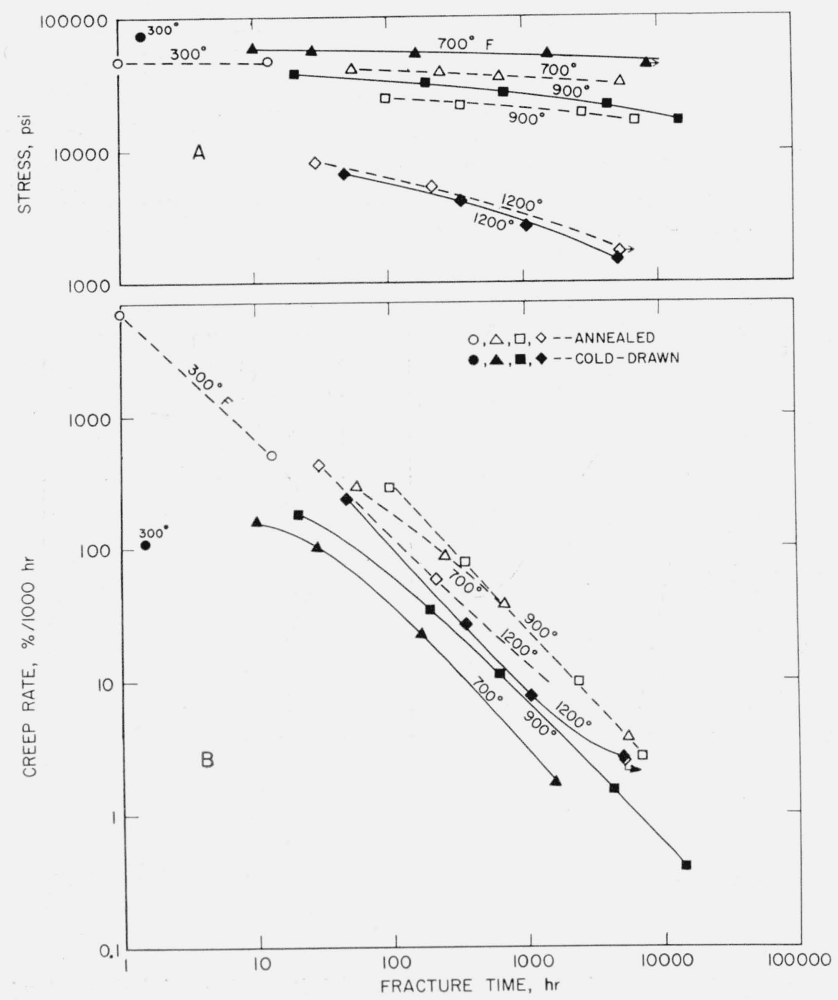

Figure 12. Relation of stress and second stage creep rate to fracture time of the annealed and cold-drawn $30 \% \mathrm{Ni}-70 \%$ Cu specimens.

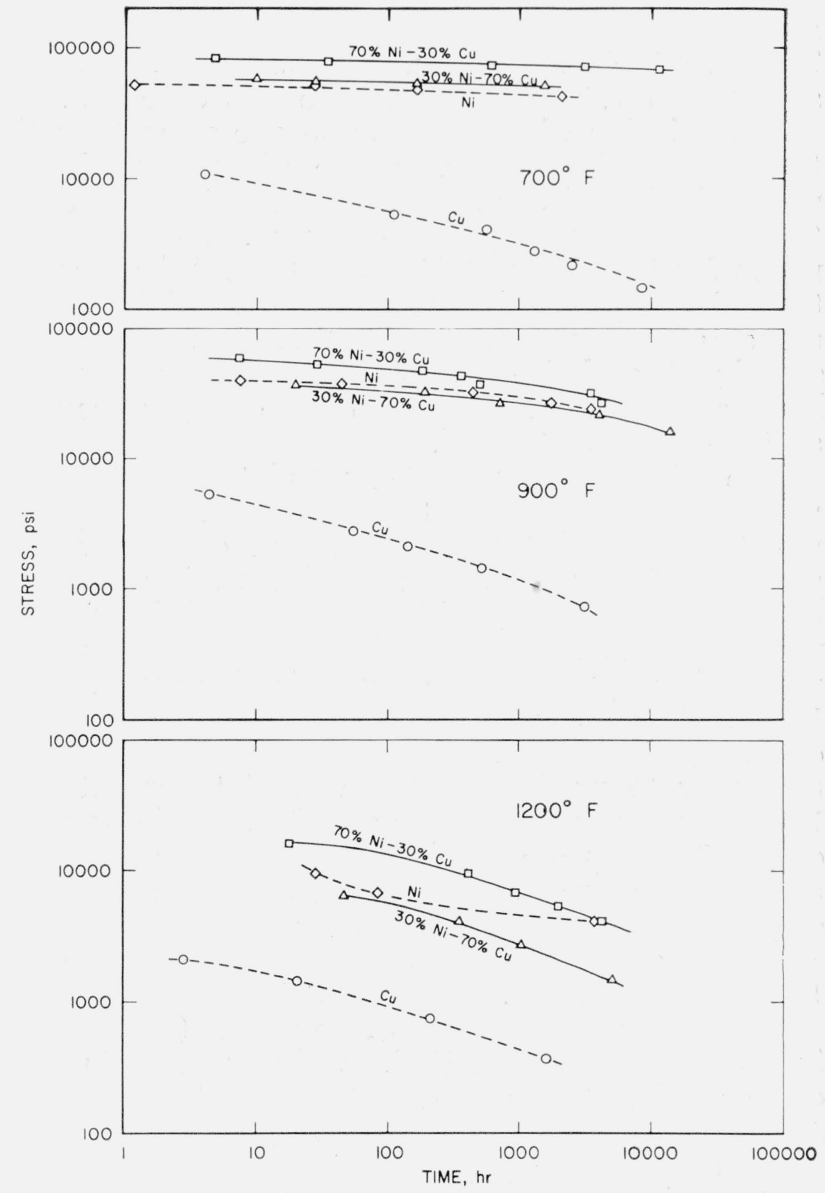

Figure 13. Relation of stress to fracture time of cold-drawn specimens at different temperatures.

cold-drawing, and composition, are shown in figures 12,13 , and 14 . As illustrated in figure $12 \mathrm{~A}$, the stress necessary to cause fracture of 30 percent Ni-70 percent $\mathrm{Cu}$ specimens at any given time increases with decrease in test temperature, and with exception of the data at $1,200{ }^{\circ} \mathrm{F}$, with colddrawing. Strengthening due to cold-drawing is more pronounced as the temperature is decreased. The second stage creep rates necessary to produce fracture at equal times were generally greater for the annealed than for the cold-drawn metal, as shown by the data in figure $12 \mathrm{~B}$. As the temperature is increased, the creep rate necessary to cause fracture in any given time increases for the cold-drawn specimens; whereas no simple relation of this type was observed for the annealed specimens. The effect of stress on fracture time at 700,900 , and $1,200{ }^{\circ} \mathrm{F}$ of the cold-drawn metals is shown in figure 13 . At each temperature, the values for the nickel and the 30 percent $\mathrm{Ni}-70$ percent $\mathrm{Cu}$ specimens were intermediate between the low values of the copper and the high values of the 70 percent Ni-30 percent $\mathrm{Cu}$ alloy. The stress level of the 30 percent $\mathrm{Ni}$ alloy is slightly higher than that of the nickel at $700{ }^{\circ} \mathrm{F}$; however, at 900 and $1,200{ }^{\circ} \mathrm{F}$ the opposite is 

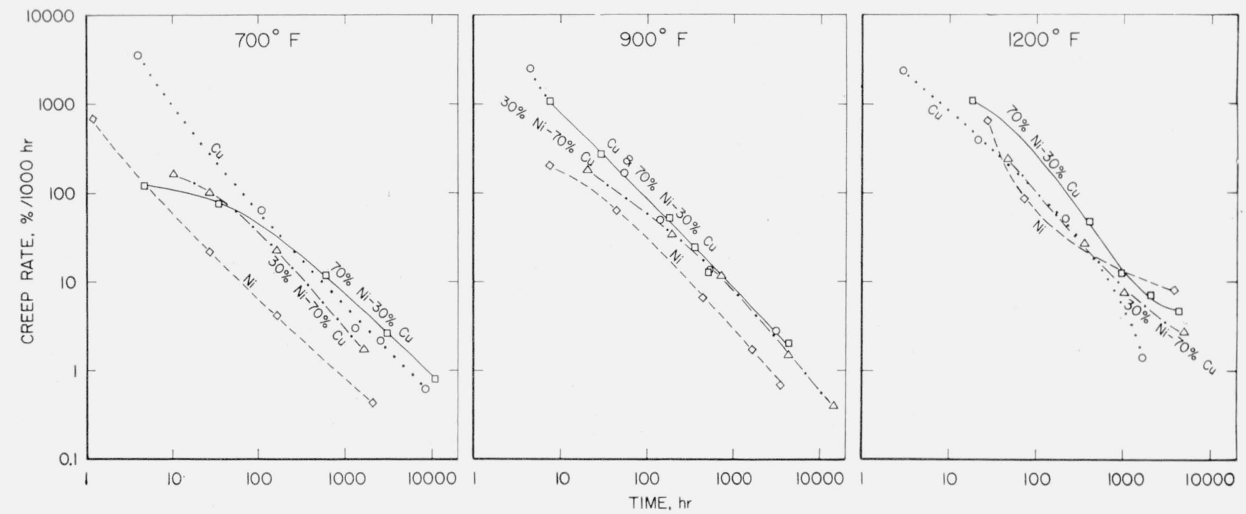

FiguRE 14. Relation of second-stage creep rate to fracture time of cold-drawn specimens at different temperatures.

true. The second stage creep rate-fracture time relations for the cold-drawn specimens are shown in figure 14. It is evident from the relative positions of the curves that no simple relation exists describing all of the variables involved. As the fracture time includes the total test time for each of the three stages of creep, apparently different types of microstructural changes occur which are dependent on the temperature, test time, and the creep rate. For different metals, the changes in structure during each of the stages are obviously different.

\subsection{Relations of Temperature, Second Stage Creep Rate, and Composition to Ductility}

Prior cold-drawing of the specimens tended to decrease the elongation and reduction of area values for specimens tested in creep below the recrystallization temperatures. Above the recrystallization temperatures, prior cold-drawing had no significant effect on the ductility. No consistent trends were observed on the relation between creep rate and elongation or reduction of area, at all temperatures, for the cold-drawn metal.
The elongation-creep rate values for the colddrawn specimens (fig. 15) indicate that one curve could describe the limited amount of data obtained at $300{ }^{\circ} \mathrm{F}$. The curves at 700 and $900{ }^{\circ} \mathrm{F}$ are another manifestation of the complexity of the mechanisms of deformation occurring at different rates and for different metals. At $1,200{ }^{\circ} \mathrm{F}$, however, elongation values generally increase with increase in nickel content and no smooth relation between second stage creep rate and ductility could be established.

Although a single curve describes the relation of creep rate to the reduction of area values at 300 ${ }^{\circ} \mathrm{F}$ of the cold-drawn metals (fig. 16), the data obtained at 700,900 , and $1,200^{\circ} \mathrm{F}$ indicate that the reduction of area increases with increase in nickel content of the specimens. However, the magnitude of the increase is affected by test temperature.

\subsection{Relation of Creep Conditions to Structures}

The effect of temperature on the tendency of the specimens tested at different rates, to contract locally (neck) is shown by the photographs of figures

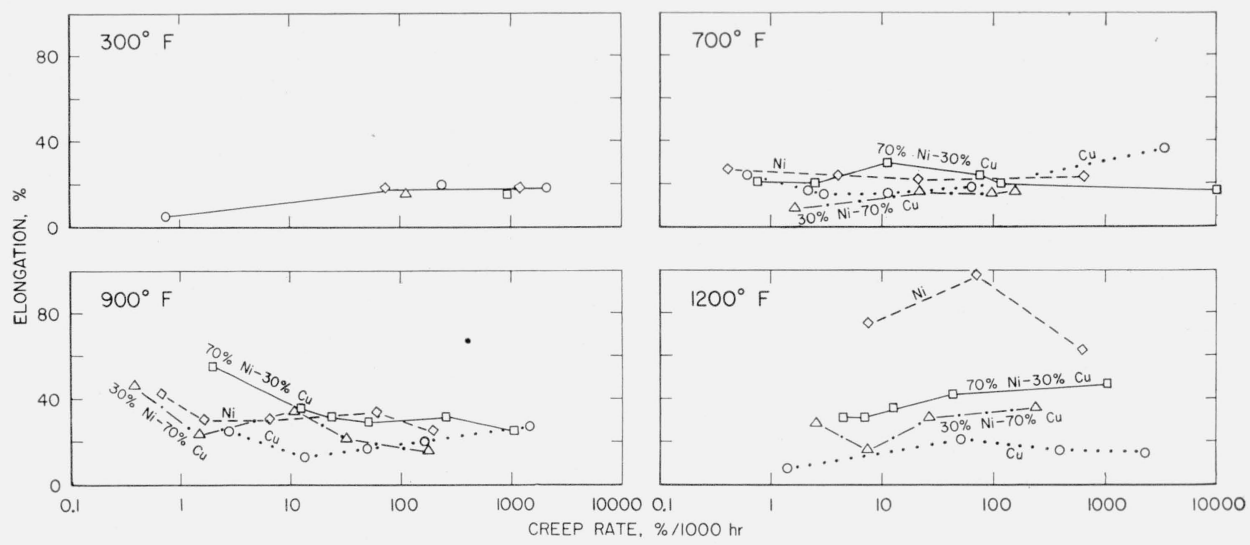

Figure 15. Relation of second stage creep rate to elongation values of specimens at different temperatures.

(Symbols used at $300^{\circ} \mathrm{F}$ correspond to those used for the metals at 700,900 , and $1,200{ }^{\circ} \mathrm{F}$.) 


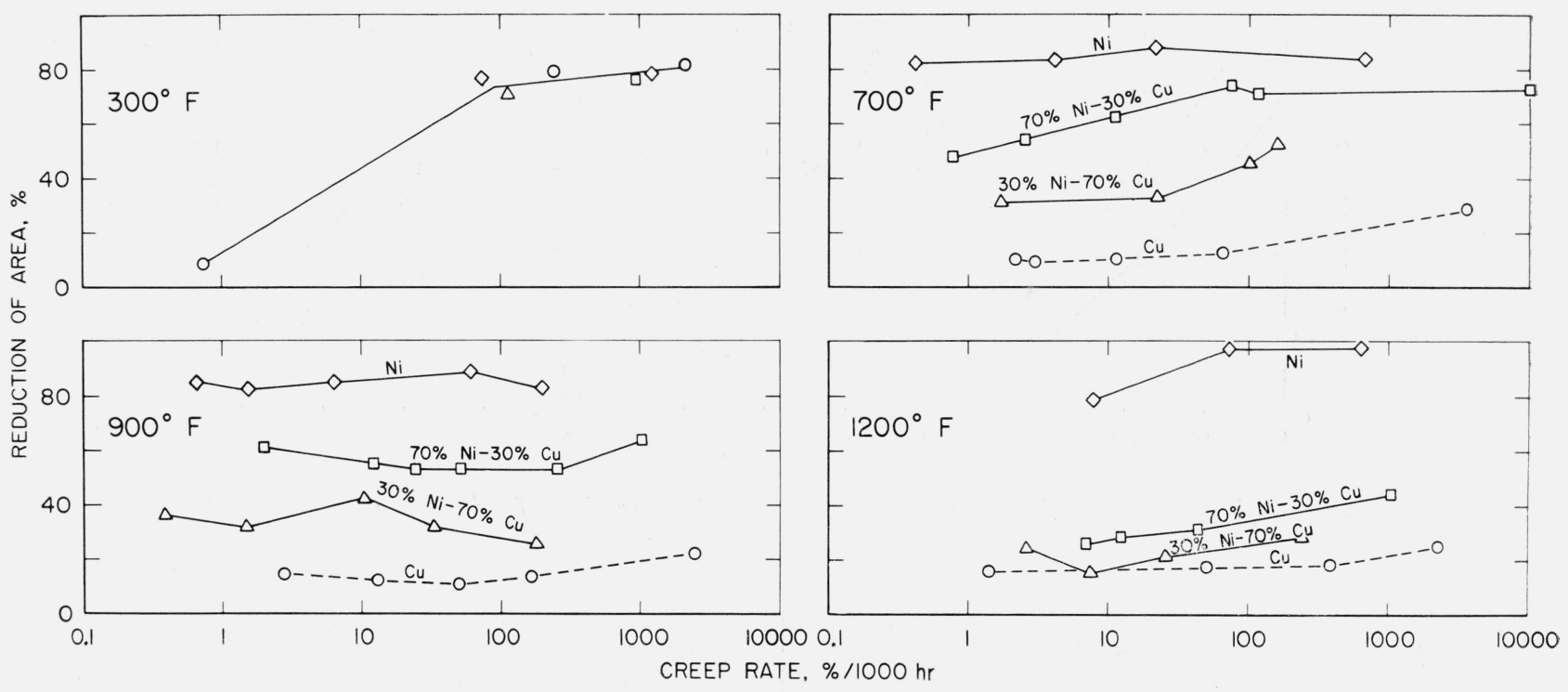

FIGURE 16. Relation of second stage creep rate to reduction of area values of specimens at different temperatures.

(Symbols used at $300{ }^{\circ} \mathrm{F}$ correspond to those used for the metals at 700,900 , and $1,200{ }^{\circ} \mathrm{F}$.)

17 and 18. The necking of specimens of copper and of the nickel-copper alloys was more pronounced as the temperature was decreased and as the creep rate was increased. Surface cracks were also more evident in the specimens tested at high temperatures and low creep rates although their presence was sometimes obscured by oxide films on the surface (figs. $17 \mathrm{G}$ and $18, \mathrm{H}$ and $\mathrm{I}$ ). The surface cracking was associated with low ductility in the specimens, whereas this phenomenon was not observed for the cold-drawn nickel specimens [9].

It has been observed [2] that during the third stage of creep, lattice defects coalesce to form voids and cracks, some of which link up to form the main path of the fracture. Some of the cracks, that were discontinuous in the interior of the specimens used in the present investigation, are shown in figures 19 and 20. Round and elliptical cracks, generally associated with transcrystalline fracture are shown in A, B, C, and D of figures 19 and 20 . Jagged cracks, the type associated with intercrystalline fracture, are more evident at the high temperatures and slow creep rates (longer fracture times), as shown in G, $\mathrm{H}$, I of figures 19 and 20 . A mixture of intercrystalline and transcrystalline cracking is illustrated by the photomicrographs in $\mathrm{E}$ and $\mathrm{F}$ of figures 19 and 20. The number of the cracks become less as the distance from the complete fracture becomes greater. Subsequent etching of these specimens showed definitely the existence of the different types of cracks in the specimens. Some of the etched specimens are shown in figure 21 . These surfaces indicate that cracking exists even at a distance of 0.4 -in. from complete fracture (fig. $21 \mathrm{C}, \mathrm{D}, \mathrm{E}$, and F) although at the lower temperatures this occurrence was very limited (fig. $21 \mathrm{~A}$ and B).
Extensive elongation of the grains, accompanied by very limited transcrystalline cracking, was evident in the cold-drawn 30 percent $\mathrm{Ni}-70$ percent $\mathrm{Cu}$ specimens tested at $700{ }^{\circ} \mathrm{F}$. A mixture of transcrystalline and intercrystalline cracks was observed for the specimen (fig. 21C) tested to fracture in 192 hr at $900^{\circ} \mathrm{F}$; whereas intercrystalline cracking, accompanied by recrystallization into small grains, predominated in the specimen tested at the same temperature for a long period of time (fig. 21D). Intercrystalline cracking, accompanied by recrystallization and the formation of equiaxed grains whose size increased with increase in test time, predominated at $1,200{ }^{\circ} \mathrm{F}$ (fig. $21 \mathrm{E}$ and $\mathrm{F}$ ).

Subboundary structures in metals have been observed for many years [15]. The literature on the influence of creep on the formation of subgrains within the parent grains has recently been reviewed [9]. Subgrains, observed after fracture of colddrawn copper and 30 percent $\mathrm{Ni}-70$ percent $\mathrm{Cu}$ creep specimens, are shown in figure 22 . The subgrain boundaries, evident for specimens strained at the lower temperatures, are apparently more effective barriers to the motion of dislocations than the subgrain boundaries existing at the higher temperatures. Some of the subgrains formed at the higher temperatures and long test times appeared to be larger than those formed at the lower temperatures. In general, the subgrain boundaries in the alloys appeared to be more distinct than those of the parent metals.

Some investigators have related the number of the etch figures to the number of dislocation sites. Triangular etch figures, developed by etching (etching time constant) the surface of the cold-drawn copper specimens used in the present investigation, are shown in figure 23. In general, it was observed 

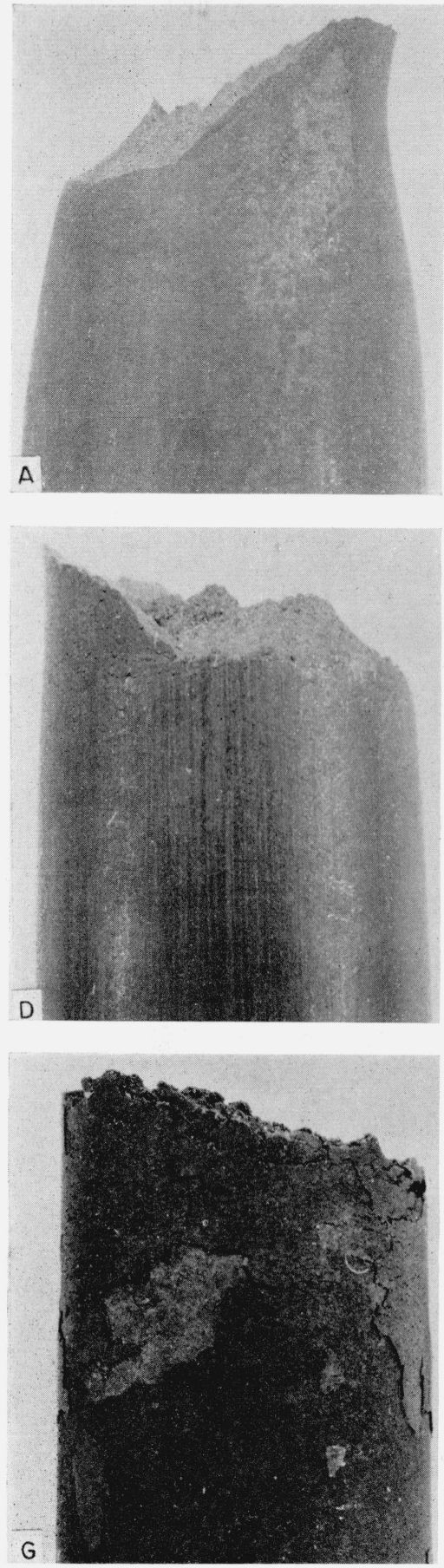
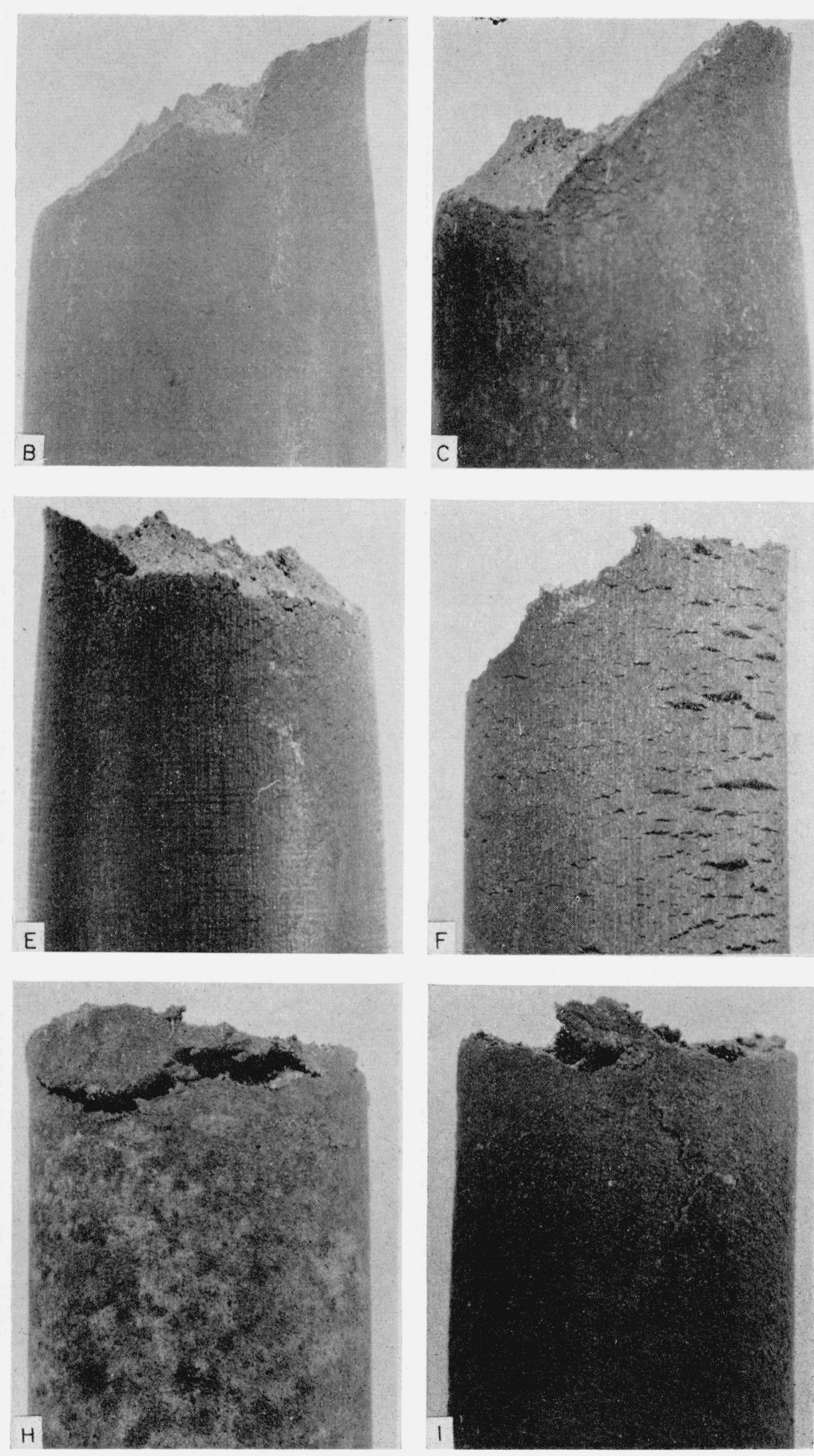

FiguRE 17. Relation of temperature and second stage creep rate to the appearance of $30 \% \mathrm{Ni}-70 \% \mathrm{Cu}$ specimens tested to complete fracture. $\times 4$.

\begin{tabular}{|c|c|c|c|c|c|c|c|c|}
\hline \multicolumn{2}{|c|}{ Temperature } & \multirow{2}{*}{$\begin{array}{c}\text { Creep } \\
\text { rate, } \\
\text { second } \\
\text { stage }\end{array}$} & \multicolumn{2}{|c|}{$\begin{array}{l}\text { Temper- } \\
\text { ature }\end{array}$} & \multirow{2}{*}{$\begin{array}{c}\text { Creep } \\
\text { rate, } \\
\text { second } \\
\text { stage }\end{array}$} & \multicolumn{2}{|c|}{$\begin{array}{l}\text { Temper- } \\
\text { ature }\end{array}$} & \multirow{3}{*}{$\begin{array}{c}\begin{array}{c}\text { Creep } \\
\text { rate, } \\
\text { second } \\
\text { stage }\end{array} \\
\begin{array}{c}\% / 1000 \mathrm{~h} \\
240\end{array}\end{array}$} \\
\hline & & & & & & & & \\
\hline A & 700 & & D & 90 & & G & 12 & \\
\hline $\begin{array}{l}\mathrm{B} \\
\mathrm{C}\end{array}$ & $\begin{array}{l}700 \\
700\end{array}$ & & $\mathrm{~F}$ & $\begin{array}{l}900 \\
900\end{array}$ & & I & $\begin{array}{l}1200 \\
1200\end{array}$ & $\begin{array}{c}26.4 \\
2.65\end{array}$ \\
\hline
\end{tabular}



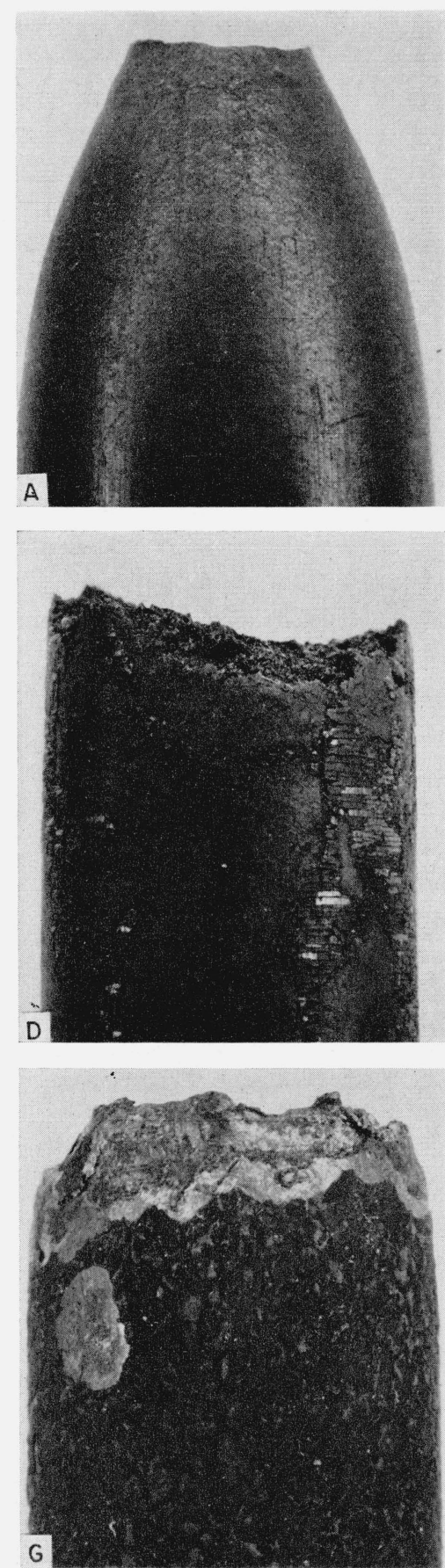
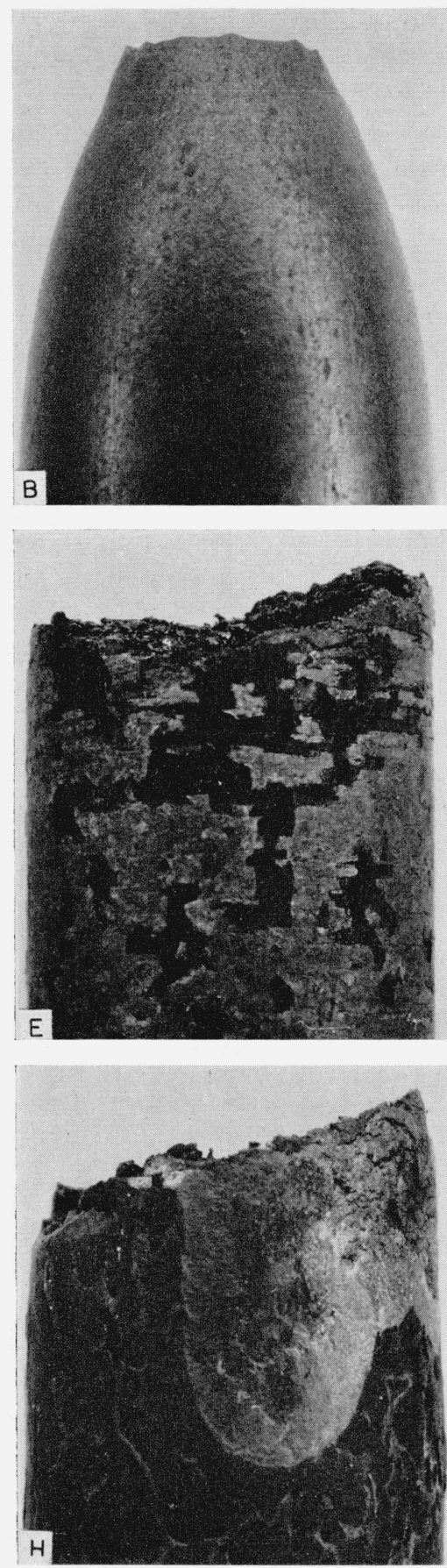
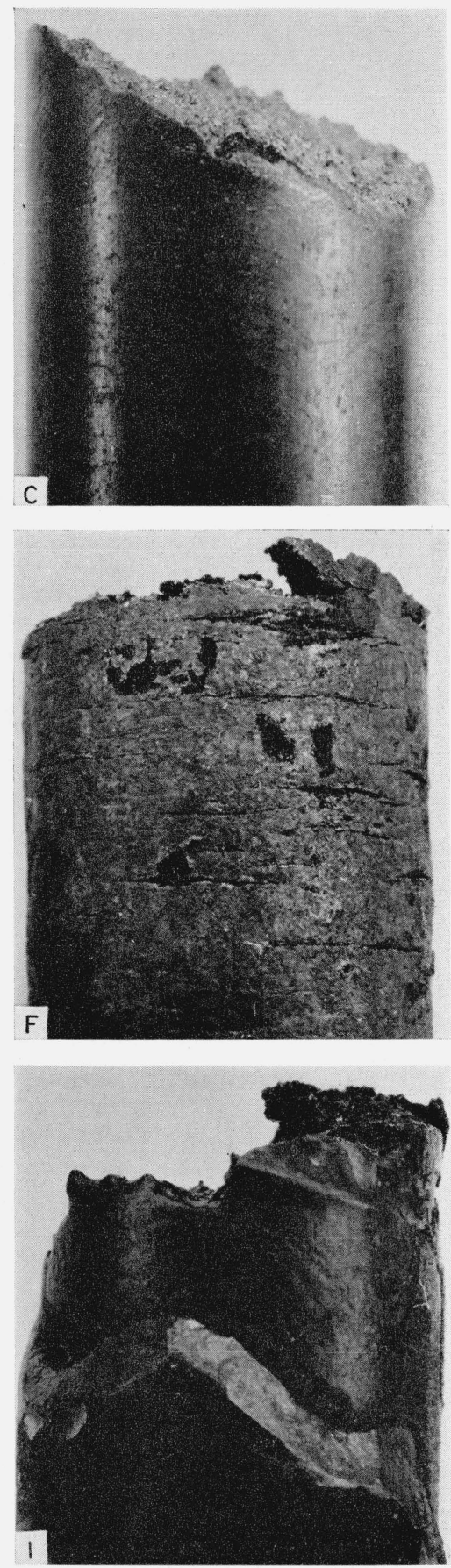

FIguRE 18. Relation of temperature and second stage creep rate to the appearance of copper specimens tested to complete fracture. $\times 4$.

\begin{tabular}{|c|c|c|c|c|c|}
\hline Temperature & $\begin{array}{l}\text { Creep } \\
\text { rate, } \\
\text { second } \\
\text { stage }\end{array}$ & $\begin{array}{l}\text { Temper- } \\
\text { ature }\end{array}$ & $\begin{array}{l}\text { Creep } \\
\text { rate, } \\
\text { second } \\
\text { stage }\end{array}$ & $\begin{array}{l}\text { Temper- } \\
\text { ature }\end{array}$ & $\begin{array}{l}\text { Creep } \\
\text { rate, } \\
\text { second } \\
\text { stage }\end{array}$ \\
\hline${ }^{\circ} \mathrm{F}$ & $\% / 1000 \mathrm{hr}$ & ${ }^{\circ} \mathrm{F}$ & $\% / 1000 \mathrm{hr}$ & ${ }^{\circ} \mathrm{F}$ & $\% / 1000 \mathrm{hr}$ \\
\hline A $\quad 300$ & 2100 & D $\quad 700$ & 3540 & 1200 & 2300 \\
\hline 300 & 240 & 700 & 11. 6 & 1200 & 50.5 \\
\hline C 300 & 0.75 & F $\quad 700$ & 0.62 & I $\quad 1200$ & 1.4 \\
\hline
\end{tabular}



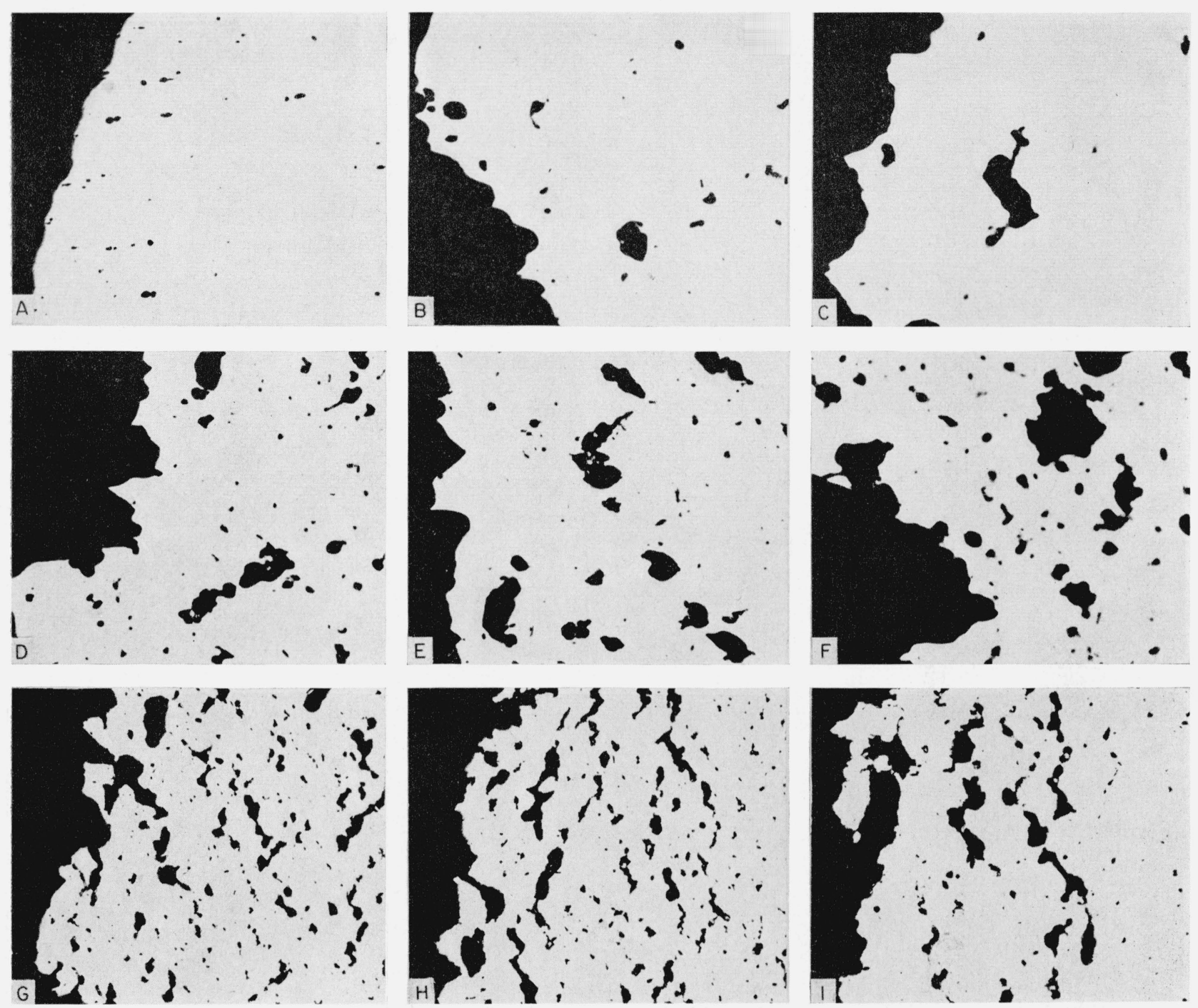

Figure 19. Relation of temperature and fracture time to microstructures of $30 \% \mathrm{Ni}-70 \% \mathrm{Cu}$ specimens.

\begin{tabular}{|c|c|c|c|c|c|}
\hline Temperature & \multirow{2}{*}{$\begin{array}{c}\begin{array}{c}\text { Fracture } \\
\text { time }\end{array} \\
h r\end{array}$} & $\begin{array}{l}\text { Temper- } \\
\text { ature }\end{array}$ & \multirow{2}{*}{$\begin{array}{c}\begin{array}{c}\text { Fracture } \\
\text { time }\end{array} \\
h r\end{array}$} & $\begin{array}{l}\text { Temper- } \\
\text { ature }\end{array}$ & \multirow{3}{*}{$\begin{array}{c}\begin{array}{c}\text { Fracture } \\
\text { time }\end{array} \\
h r \\
47.5\end{array}$} \\
\hline${ }^{\circ} \mathrm{F}$ & & ${ }^{\circ} \mathrm{F}$ & & ${ }^{\circ} \mathrm{F}$ & \\
\hline A 300 & 1.5 & D 900 & 20 & 1200 & \\
\hline 700 & 10 & 900 & 710 & 1200 & 355 \\
\hline 700 & 1550 & 900 & 14044 & 1200 & 5002 \\
\hline
\end{tabular}

that increasing the test temperature or decreasing the creep rate tended to increase the size and decrease the number of the etch figures. Furthermore, the etch figures were more evident within the grains than at the grain boundaries.

\section{Summary}

Creep tests were made in tension at 300, 700, 900, and $1,200{ }^{\circ} \mathrm{F}$ on specimens of copper, nickel, a 70 percent Ni-30 percent $\mathrm{Cu}$ alloy, and a 30 percent $\mathrm{Ni}-70$ percent $\mathrm{Cu}$ alloy, initially cold-drawn to 40 percent reduction in area.
Conformance to the parabolic strain-time law was evident over limited ranges of stress, strain, and temperature.

Cold-drawing the metals, prior to testing below the recrystallization temperatures, tended: (1) to increase the stresses necessary to produce equal creep rates; (2) to displace the creep stress-fracture time curves to higher values of stress; (3) to displace the creep rate-fracture time curves to lower values of creep rate; (4) to decrease the elongation and reduction of area values; (5) and to change the rate sensitivity. Above the recrystallization tempera- 

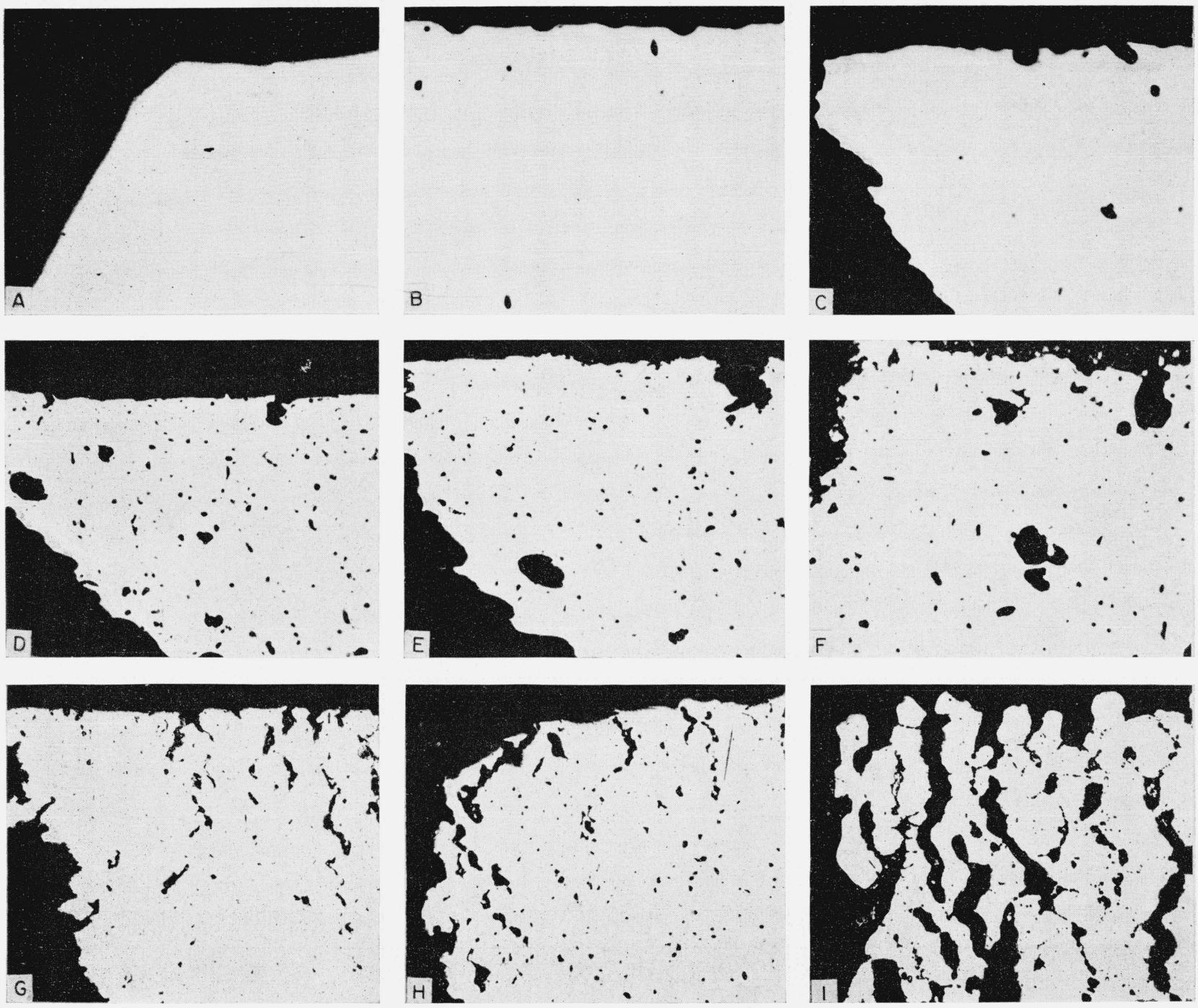

FIGURE 20. Microstructures near surface near fracture of $30 \%$

$\mathrm{Ni}-70 \% \mathrm{Cu}$ specimens tested at different temperatures and stresses. Unetched $\times 75$.

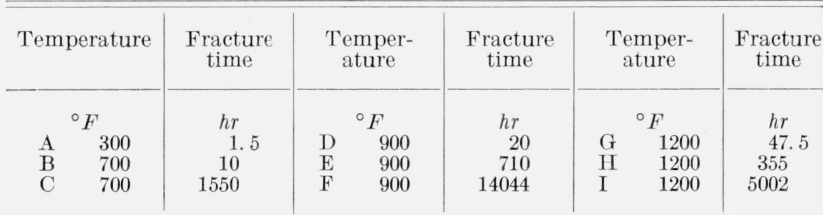

tures, the strength and ductility values were affected only slightly by prior cold-drawing.

The 70 percent Ni-30 percent $\mathrm{Cu}$ alloy generally showed the greatest resistance to creep and copper the least. The nickel was stronger than the 30 percent Ni-70 percent $\mathrm{Cu}$ alloy at 900 and $1,200{ }^{\circ} \mathrm{F}$ and weaker at $700{ }^{\circ} \mathrm{F}$.

Strengthening of the alloys above that of the base metals was most marked at $700^{\circ} \mathrm{F}$ and at the higher creep rates.

Although the rate sensitivities increased with increase in temperature, no smooth relation was shown between this property and chemical composition of the metals.

Reduction of area values obtained on specimens tested at 700,900 , and $1,200{ }^{\circ} \mathrm{F}$ and elongation values at $1,200{ }^{\circ} \mathrm{F}$ increased with increase in nickel content. No smooth relation was observed for elongation values at 700 and $900^{\circ} \mathrm{F}$. The ductility at $300{ }^{\circ} \mathrm{F}$ appeared to be independent of chemical composition.

The degree of necking of the specimens decreased and the tendency toward intercrystalline fracture increased with decrease in creep rate and, except the nickel, with increase in test temperature. 


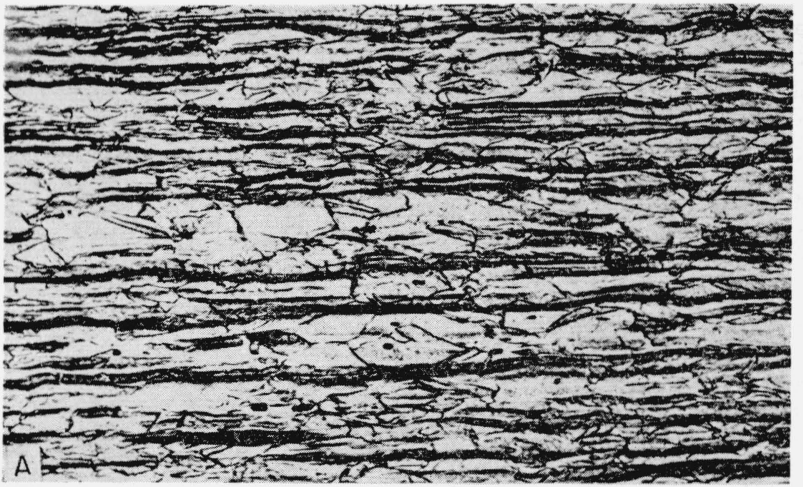

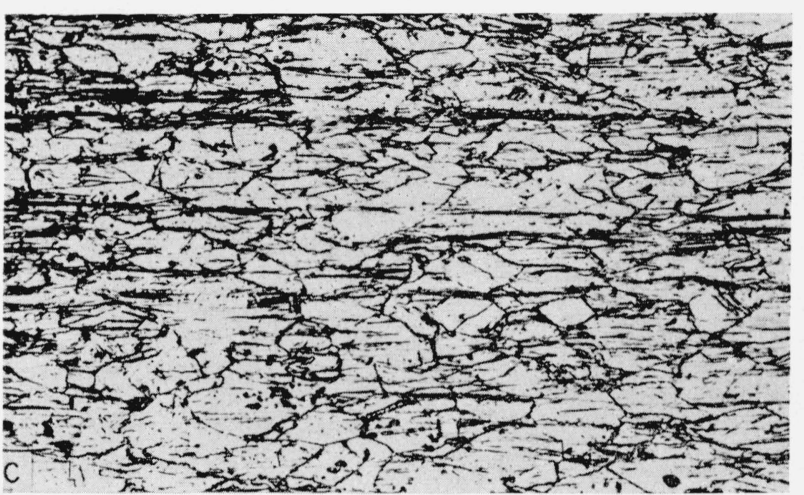

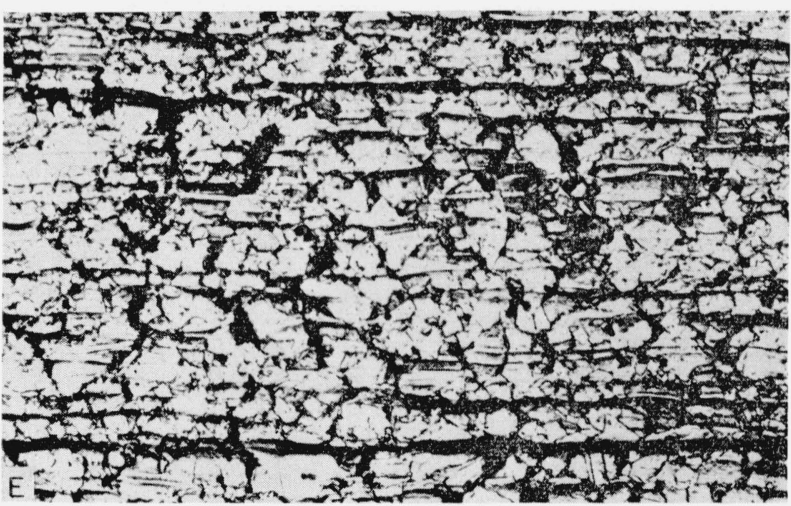

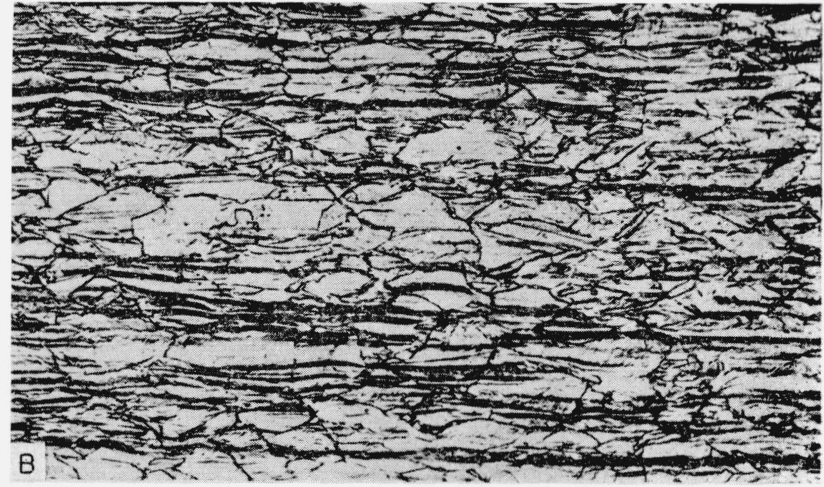

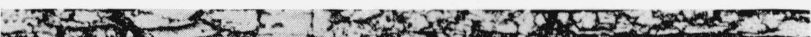

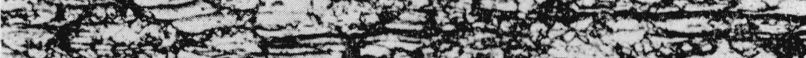

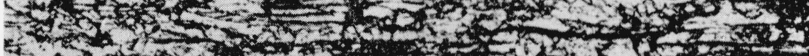

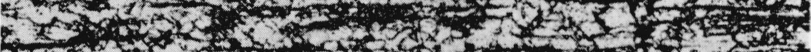

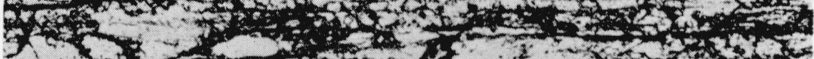

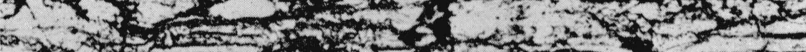

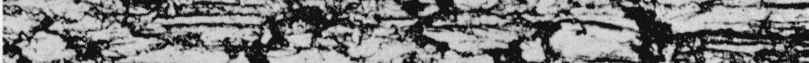

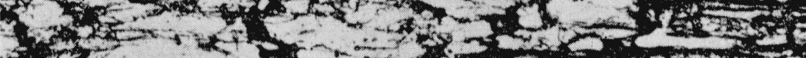

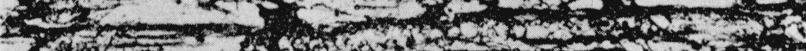

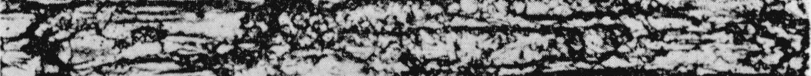

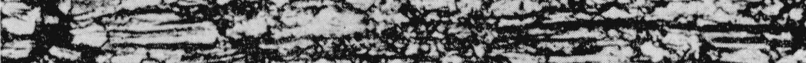

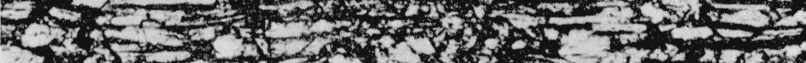
D. 3 .

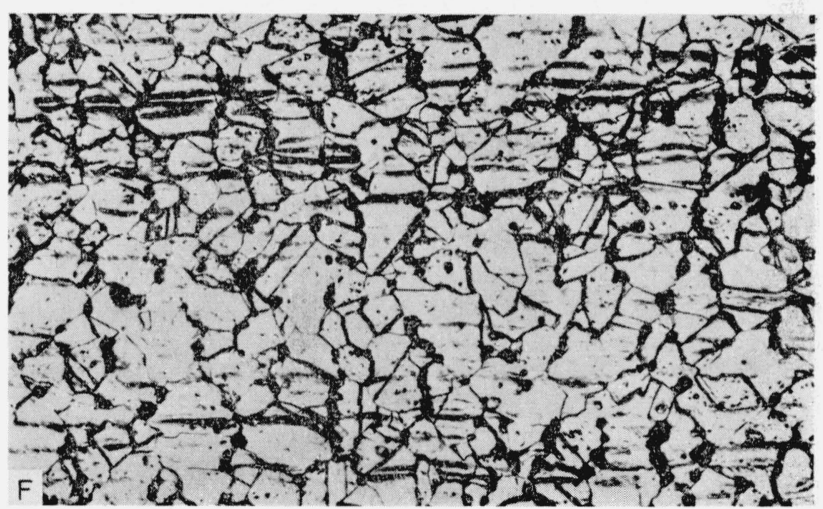

Figure 21. Microstructures, near axis, approximately 0.4"

from fracture of $30 \% \mathrm{Ni}-70 \% \mathrm{Cu}$ specimens.

$\mathrm{T}$ he point of fracture is to the left of each photomicrograph. Longitudinal sec-

tions, etched in $20 \mathrm{~g} \mathrm{CrO}_{3}, 3.75 \mathrm{~g} \mathrm{NH}_{4} \mathrm{Cl}, 25 \mathrm{~cm}^{3} \mathrm{HNO}_{3}$ (conc.), $25 \mathrm{~cm}^{3} \mathrm{H}_{2} \mathrm{SO}$

(conc.) and $450 \mathrm{~cm}^{3} \mathrm{H}_{2} \mathrm{O}, \times 100$

\begin{tabular}{|c|c|c|c|c|c|}
\hline Temperature & $\begin{array}{c}\text { Fracture } \\
\text { time }\end{array}$ & $\begin{array}{l}\text { Temper- } \\
\text { ature }\end{array}$ & $\begin{array}{c}\text { Fracture } \\
\text { time }\end{array}$ & $\begin{array}{l}\text { Temper- } \\
\text { ature }\end{array}$ & $\begin{array}{c}\text { Fracture } \\
\text { time }\end{array}$ \\
\hline${ }^{\circ} \mathrm{F}$ & $h r$ & ${ }^{\circ} \mathrm{F}$ & $h r$ & ${ }^{\circ} \mathrm{F}$ & $h r$ \\
\hline 700 & 28 & C $\quad 900$ & 192 & 1200 & 47.5 \\
\hline 700 & 1550 & 900 & 14044 & 1200 & 1032 \\
\hline
\end{tabular}

The largest subgrains with the most sharply defined boundaries were obtained for the specimens having the longest test times.
The size of the "etch figures" increased and their number decreased with increase in test temperature and with decrease in creep rate. 

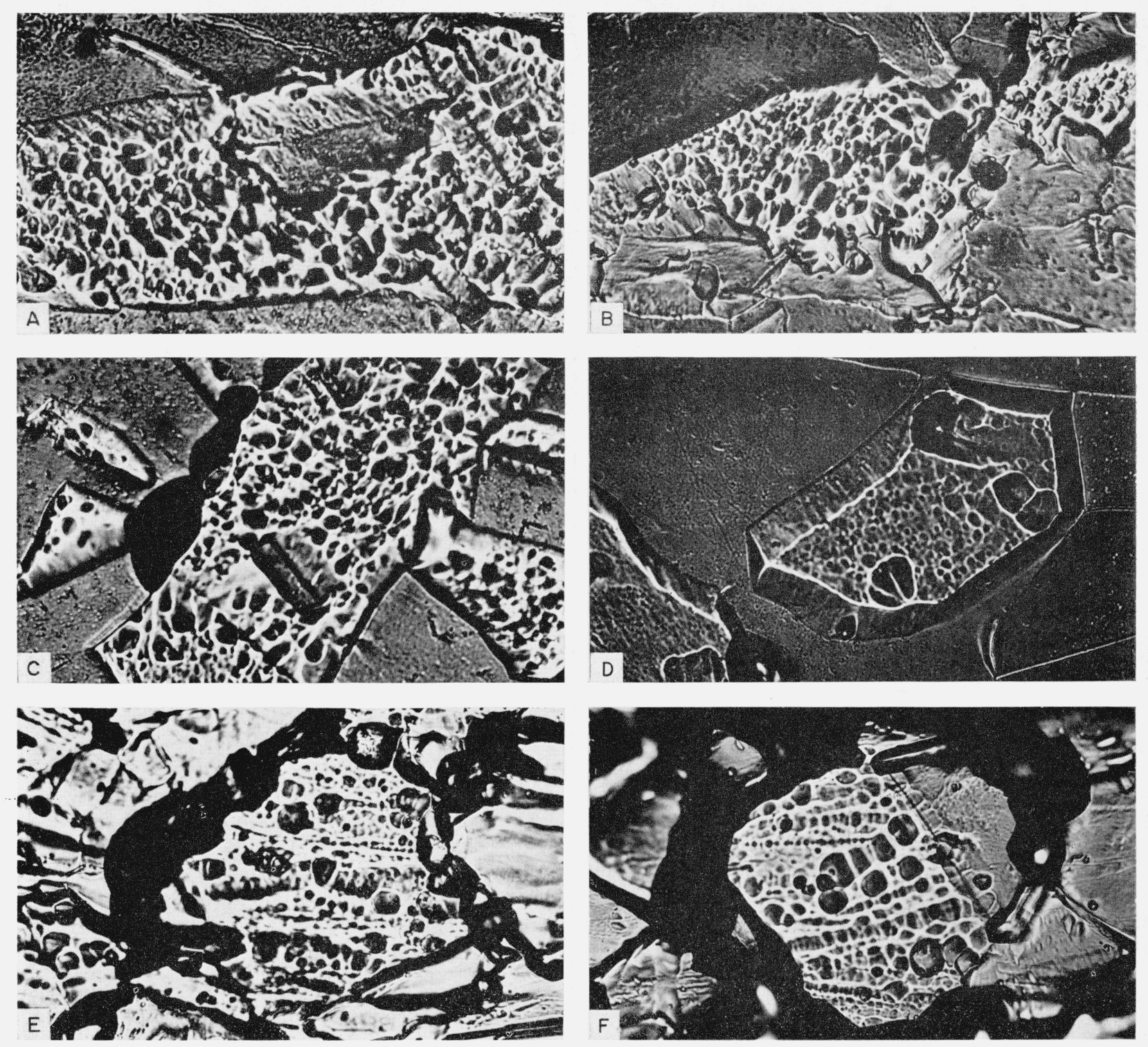

Figure 22. Subgrains in specimens after fracture at different temperatures.

Longitudinal sections A, B, C, D etched in equal parts $\mathrm{NH}_{4} \mathrm{OH}, \mathrm{H}_{2} \mathrm{O}_{2}(3 \%)$, and $\mathrm{H}_{2} \mathrm{O}$. E and $\mathrm{F}$ etched in $20 \mathrm{~g} \mathrm{Cr} \mathrm{O}_{3}, 3.75 \mathrm{~g} \mathrm{NH}_{4} \mathrm{Cl}, 25 \mathrm{~cm}^{3} \mathrm{HNO}_{3}$ (conc.), 25 $\mathrm{cm}^{3} \mathrm{H}_{2} \mathrm{SO}_{4}$ (conc.) and $450 \mathrm{~cm}^{3} \mathrm{H}_{2} \mathrm{O}$

\begin{tabular}{|c|c|c|c|c|}
\hline \multicolumn{2}{|r|}{ Metal } & Temper- & Fracture & Magnifi- \\
\hline $\begin{array}{l}\mathrm{A} \\
\mathrm{B} \\
\mathrm{C} \\
\mathrm{D} \\
\mathrm{E} \\
\mathrm{F}\end{array}$ & $\begin{array}{l}\text { OFHC Cu} \\
\quad \text { do } \\
30 \% \mathrm{do}-70 \% \mathrm{Cu} \\
\end{array}$ & $\begin{array}{r}{ }^{\circ} F \\
300 \\
700 \\
900 \\
1200 \\
1200 \\
1200\end{array}$ & $\begin{array}{c}h r \\
1945 \\
4 \\
54.5 \\
1606 \\
355 \\
5002\end{array}$ & $\begin{array}{r}\times 1000 \\
\times 1000 \\
\times 1000 \\
\times 1000 \\
\times 500 \\
\times 500\end{array}$ \\
\hline
\end{tabular}




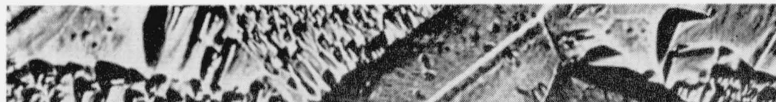

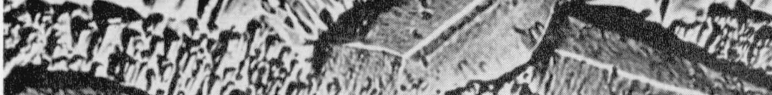

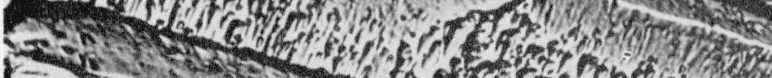

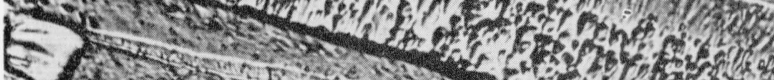
of 1 .

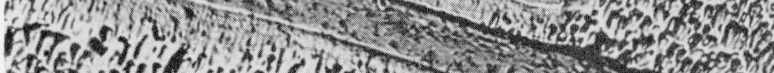
70 of

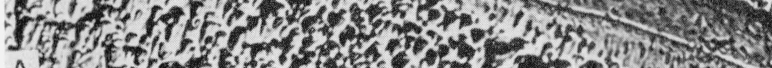

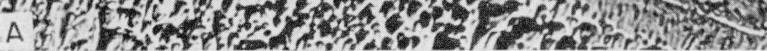
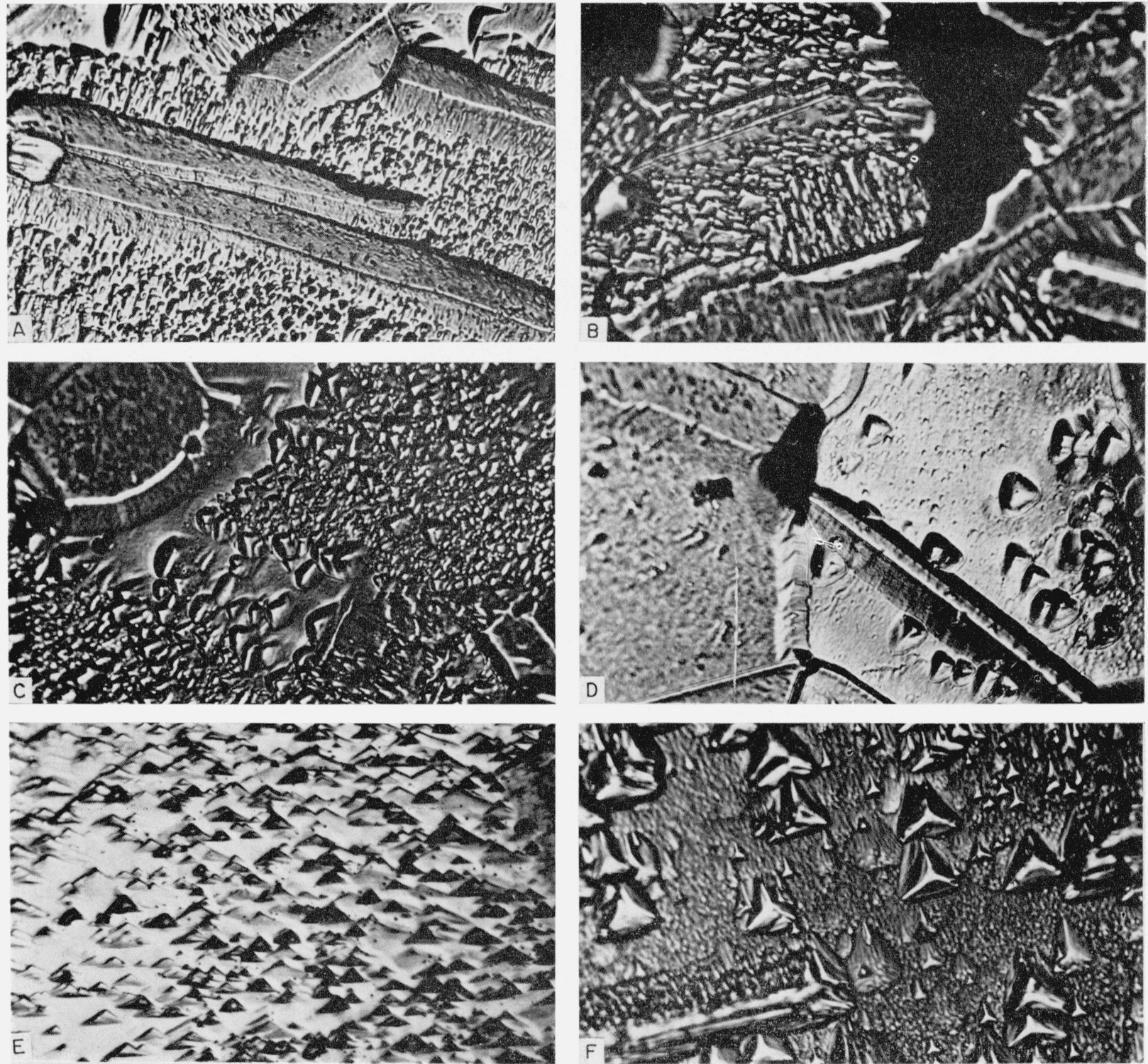

FiguRE 23. Relation of temperature and second stage creep rate to the size and distribution of "etch figures" in OFHC

copper specimens after fracture at different temperatures and

stresses.

Longitudinal sections, etched in equal parts $\mathrm{NH}_{4} \mathrm{OH}, \mathrm{H}_{2} \mathrm{O}_{2}(3 \%)$ and water.

1000 .

\begin{tabular}{|c|c|c|}
\hline \multicolumn{2}{|c|}{$\begin{array}{l}\text { Temper- } \\
\text { ature }\end{array}$} & $\begin{array}{l}\text { Creep rate, } \\
\text { second stage }\end{array}$ \\
\hline \multicolumn{2}{|c|}{${ }^{\circ} F$} & $\% / 1000 \mathrm{hr}$ \\
\hline A & 700 & 64 \\
\hline B & 700 & 0. 62 \\
\hline $\mathrm{C}$ & 900 & 166 \\
\hline D & 900 & 2. 75 \\
\hline E & 1200 & 2300 \\
\hline $\mathrm{F}$ & 1200 & 1.4 \\
\hline
\end{tabular}




\section{References}

[1] W. D. Jenkins and T. G. Digges, Creep of high-purity copper, J. Research NBS 45, 153 (1950) RP2121.

[2] W. D. Jenkins and T. G. Digges, Creep of annealed and cold-drawn high-purity copper, J. Research NBS 47, 272 (1951) RP2254.

[3] W. D. Jenkins and T. G. Diges, Effect of temperature on the tensile properties of hioh-purity nickel, J. Research NBS 48, 313 (1952) RP2317.

[4] W. D. Jenkins and T. G. Digges, Influence of prior strain history on the tensile properties and structures of highpurity copper, J. Research NBS 49, 167 (1952) RP2354.

[5] W. D. Jenkins, T. G. Digges, and C. R. Johnson, Creep of high-purity nickel, J. Research NBS 53, 329 (1954) RP2551.

6] W. D. Jenkins, T. G. Digges, and C. R. Johnson, Effect of temperature on the tensile properties of a commercial and a high-purity 70-percent-nickel-30-percentcopper alloy, J. Research NBS 54, 21 (1955) RP2561.

[7] W. D. Jenkins, T. G. Digges, and C. R. Johnson, Tensile properties of copper, nickel, and 70-percent-copper-30percent-nickel and 30-percent-copper-70-percent-nickel alloys at high temperature, J. Research NBS 58, 201 (1957) RP2753.
[8] W. D. Jenkins and C. R. Johnson, Creep of annealed nickel, copper, and two nickel-copper alloys, J. Research NBS 60. 173 (1958) RP2836.

[9] W. D. Jenkins and C. R. Johnson, Creep of cold-drawn nickel, J. Research NBS 63C (Eng. and Instr.) No. 1, 1 (1959).

[10] E. R. Parker and T. H. Hazlett, Principles of solution hardening, Seminar on Relation of Properties of Microstructure, Am. Soc. Metals 30, (Cleveland, Ohio, 1953); Trans. ASME 46A, (1954).

[11] Seminar on creep and recovery of metals, Trans. Am. Soc. Metals, 49A, (1957).

[12] P. G. McVetty, Creep of metals at elevated temperatures. The hyperbolic-sine relation between stress and creep rate, Trans. Am. Soc. Mech. Engrs. 65, 761 (1943).

[13] F. R. Larson and J. Miller, A time-temperature relationship for rupture and creep stresses, Trans. Am. Soc. Mech. Engrs. 74, 765 (1952).

[14] J. D. Lubahn, Simultaneous aging and deformation in metals, Trans. AIME, 185, 702 (1949).

[15] L. Northcott, Veining or sub-boundary structures, J. Iron and Steel Inst. (London) 162, 267 (1932).

(Paper 66C1-88). 


\section{Publications of the National Bureau of Standards*}

\section{Selected Abstracts}

Physical entities and mathematical representation, C. H Page, J. Research NBS 65B (Math. and Math. Phys.) No. 4 (Oct.-Dec. 1961) ro cents.

Certain basic postulates about physical observables yield the structure of their mathematical representation. Measure equations are contrasted with quantity equations, and measurement units with abstract units. The abstract vector spaces in which observables are represented comprise the core of dimensional analysis.

Systems of equations, units, and dimensions are discussed, along with comments on rationalization. The problem of assigning a dimension to angle is discussed, and a new proposal offered.

Circumferentially uniform electroplating of tube bores, J. F. Young and H. I. Salmon, Plating 48, No. 7,$783 ; 88 \%-8$ (July 1961).

New procedures for plating the internal surface of tubes are described. Data are presented giving the degree of circumferential uniformity of thickness of deposits of chromium obtained with newly designed fixtures. The best procedure, in which a rotating anode was centered and insulated by a spirally wound rod of polyvinyl-chloride, resulted in deposits that deviated from uniformity by only 2 percent of the average thickness. The gun tubes used in this study had an inside diameter of 0.3 inch and a bore length of 20 inches.

Residual losses in a guard-ring micrometer-electrode holder for solid-disk dielectric specimens, A. H. Scott and W. P. Harris, 1960 Annual Report, Conference on Electrical Insulation, Natl. Acad. Sci.-Natl. Research Council, 11-17 (1961). A guard-ring micrometer-electrode holder especially designed for use in making dielectric measurements on solid-disk specimens of low-loss materials has been constructed. A method of determining the separation of the electrodes to \pm 1 micron, using ball reference gages, is described. Residual losses in the guard-ring holder, and also in the bridge standard capacitor used in the Schering bridge employed for the measurements, caused by losses in surface films on the electrodes and by series resistance in the leads, were accurately measured. It is shown that at frequencies from 100 cycles per second to 100 kilocycles per second these residual losses are not more than a few microradians. Using corrections thus obtained, the holder-bridge combination can be used to measure the losses of low-loss materials with greater accuracy than heretofore.

Comparative $p \mathrm{H}$ measurements on papers by water extraction and glass electrode spot tests, J. H. Flynn and L. E. Smith, Tappi 44, No. 3, 223-228 (March 1961).

The $p \mathbf{H}$ of a large number of experimental and commercial papers was determined by the TAPPI T435 cold extraction method and a method in which glass-calomel electrodes were pressed against the surface of the papers, moistened with either distilled water or $0.1 \mathrm{~N} \mathrm{KCl}$.

The use of $\mathrm{KCl}$ instead of water gave better reproducibility less time variation, and values, on an average, about $0.4 p \mathrm{H}$ units lower.

Correlation between the spot tests and extraction $p H$ 's was rather poor, especially for papers of high extraction $p \mathrm{H}$. Few generalizations could be made concerning the effect of the types of pulps or added chemicals upon the $p \mathrm{H}$ values. It appears that other variables in the papermaking, blending, and pulping cause considerable variation in measured $p H$ values of the paper.

Because of the complicated nature of the chemical and physical processes involved, none of the methods can be judged to be superior per se, but the spot test merits consideration in cases where a quick nondestructive method is needed.
An analysis of errors in the calibration of electric instruments, F. I. Hermach, Communication and Electronics, 1-6 (May 1961).

The often-stated rule of thumb that a standard must be "10 times as accurate as the instrument to be tested" is evaluated by an analysis of errors in tests of electrical instruments, and is illustrated by examples. If each standard is calibrated periodically and if corrections are applied so that determinate systematic errors are eliminated a much smaller ratio suffices. Such analyses, which are not difficult to make, should replace arbitrary accuracy ratios because of the economic and technical importance of correctly choosing standards, particularly in multiechelon systems of standardizing laboratories.

Optical calibration of vibration pickups at small amplitudes, V. A. Schmidt, S. Edelman, E. R. Smith, and E. Jones, J. Acoust. Soc. Am. 33, No. 6, 748-751 (June 1961).

A photometric device for accurately measuring the amplitudes of sinusoidal vibrations is described. The device is designed for calibrating vibration pickups. The apparatus employs a Fizeau-type interferometer with a photomultiplier observing the fringe pattern. The method is applied to the measurement of vibrations throughout the audio and near ultrasonic frequency range with amplitudes ranging from $72 \AA$ to $4400 \AA$. Extension to amplitudes as low as $5 \AA$ can be made with some modification to the apparatus.

Simple adiabatic demagnetization apparatus, V. D. Arp and R. H. Kropschot, Rev. Sci. Instr. Note 32,217-218 (Feb. 1961). A simple and inexpensive adiabatic demagnetization apparatus which uses a superconducting solenoid and an appropriate paramagnetic salt is described. The solenoid is wound with niobium wire and produces three kilogauss. Dysprosium ethyl sulfate is chosen as the paramagnetic salt for its chemical stability, high heat capacity, and high magnetic susceptibility. Temperatures of the order of $0.1^{\circ} \mathrm{K}$ can be attained.

An interferometric instrument for the rapid measurement of small diameters, D. H. Blackburn, Rev. Sci. Instr. 32, No. 2, 137 (Feb. 1961).

An instrument was developed for the rapid and accurate measurement of small diameters. The operating procedure consists of placing the test fiber between two optically flat surfaces and, using the fiber as a fulcrum, adjusting the upper flat until the surfaces are parallel, utilizing the absence of interference fringes between the surfaces to indicate parallelism. Controlled tilting of the upper flat is obtained by adjusting, with a micrometer screw, a sliding wedge under a lever attached to the upper flat. Fiber diameter is a linear function of wedge position as indicated by micrometer screw setting.

Low-temperature thermocouples. I. Gold-cobalt or constantan versus copper or "normal" silver, R. L. Powell, M. D. Bunch, and R. J. Corruccini, Cryogenics 1, 139-150 (Mar. 1961).

An apparatus for calibrating thermocouples from $4^{\circ}$ to $300{ }^{\circ} \mathrm{K}$ is described. The reference junctions are in a lower chamber kept at fixed temperatures by various boiling cryogenic fluids. The variable junctions are in a gas-filled upper chamber. The temperatures of the upper chamber are determined by a helium gas thermometer below $20^{\circ} \mathrm{K}$ and by a calibrated platinum thermometer above that. The apparatus has been used to obtain a detailed calibration table of the thermoelectric power and potential difference for constantan, gold-cobalt (Au-2.1 At \% Co), and "normal" silver (Ag-0.37 At \% Au) versus copper. At low temperatures the gold-cobalt versus copper has a significantly larger thermoelectric power than does constantan versus copper (respectively 16 and $6 \mu \mathrm{v} /{ }^{\circ} \mathrm{K}$ at $20^{\circ} \mathrm{K}$ ), but unfortunately it is also more inhomogeneous, so that uncertainties in temperature measurement are approxi- 
mately the same. The "normal" silver has a very small thermoelectric power versus copper. Results are included of inhomogeneity, annealing, and long-time stability tests.

A transistor frequency meter, F. R. Bretemps and S. Saito, Electronic Inds. 19, No. 10, 196-190 (Oct. 1960).

A transistor frequency meter is described which is used for checking signal generators. A 1 Mc crystal is used for comparison. Power is supplied by a single mercury cell and loudspeaker operation is obtained.

Self-qualification of laboratories, A. T. McPherson, Instr. and Control Systems 34, No. 7, 1265 (July 1961).

A plan is presented whereby objective standards can be established to enable a calibration or testing laboratory to rate itself with regard to: (1) the qualifications of its staff, (2) the adequacy of its facilities and equipment for the work undertaken, and (3) its performance in the periodic measurement or testing of "unknown" reference samples. Under the plan, standards would be set up in the specific fields in which the interest would be sufficient to warrant the expense of a reference-sample program. The standards would be established by one or more central, nongovernmental agencies in which the laboratories, their customers, and independent scientific experts would be equally represented. The laboratories participating in the plan would be authorized to report or publish their qualifications on a standard form.

Post office mechanization, B. M. Levin, M. C. Stark, and P. C. Tosini, Elec. Engr. 80, 105-110 (Feb. 1961).

An approach to the mechanization of letter sorting called "codesorting" is presented. This approach utilizes a computer as an integral part of the system. The operational characteristics and requirements of the computer are emphasized.

The precision measurement of transformer ratios, R. D. Cutkosky and J. Q. Shields, IRE Trans. Instrumentation I-9, No. 2, 243-250 (Sept. 1960).

A procedure for measuring the voltage ratio between the two secondary windings of a three winding transformer is described. The application of this procedure to the calibration of transformers with ten-to-one ratios is discussed in detail. Explicit formulas are developed which correct for the finite lead impedances and load admittances associated with the measuring system, and yield a value for the opencircuit transformer ratio. Detailed calculations are presented for measurements performed on a given transformer with results believed to be accurate to a few parts in $10^{9}$.

Electrodes for pH measurement, R. G. Bates, J. Electroanalytical Chem. 3, 93 (1961).

The experimental $p \mathrm{H}$ value is defined in terms of a difference in the electromotive force or tension of a $p \mathrm{H}$ cell containing 1 ) the unkown" solution and 2) a standard solution of assigned $p \mathrm{H}$. The $p \mathrm{H}$ cell consists of a reference electrode, a liquid junction, and an electrode whose potential is a function of $p \mathrm{H}$. The potential or tension of the reference electrode, including that at the liquid junction, is assumed to remain unchanged while measurements (1) and (2) are being made and during the time interval between these measurements.

Although the glass electrode is the most common $p \mathrm{H}$-responsive electrode, the hydrogen electrode, the quinhydrone electrode, and the antimony electrode all have their place in $p \mathrm{H}$ measurements. This paper describes these four indicator electrodes; discusses the advantages, limitations, and accuracy of each one; and summarizes the information needed for a selection of the best electrode for each special measuring situation.

A precision RF attenuation calibration system, C. M. Allred and C. C. Cook, IRE Trans. Instrumentation I-9, No. 2, 268-274 (Sept. 1960).

A new precision attenuation-calibrating system with greatly increased sensitivity, stability, and measurement range has been completed at the National Bureau of Standards, Boulder Laboratories. The increased stability and sensitivity are achieved by the use of a highly accurate piston attenuator and precision phase shifter combined into a null system. The extended attenuation measurement range has been obtained by using a new mode launching system which is excited by essentially a constant current source of very high magnitude. The padding necessary for correct impedance matching is kept at a minimum by use of a special non-interactive combining network.

A vibrating sample magnetometer, N. V. Frederick, IRE Trans. Instrumentation I-9, No. 2, 194-196 (Sept. 1960).

A vibrating sample magnetometer has been designed and constructed. The instrument combines the advantages of the techniques employed by Smith and Foner. The instrument employs the pickup coil and sample geometry of Smith's instrument and a vibration and measurement technique similar to that used by Foner. This combination of techniques makes unnecessary any modifications of the magnet employed and yet provides a system which is self-calibrating. The sample is mounted at the end of a Vycor" glass rod which is mounted in the plane of the magnet gap. The rod is vibrated in its gravest flexural mode. The vibration frequency and amplitude are controlled by feedback circuitry. The glass rod acts as a stable frequency source. The sample is vibrated parallel to the magnetic field and normal to the plane of the pickup coils which are mounted upon the magnet pole pieces. The voltage induced in the pickup coils is measured by a feedback amplifier-voltmeter which allows accuracy of approximately one percent.

A standard current transformer and comparison methodA basis for establishing ratios of currents at audio frequencies, B. L. Dunfee, IRE Trans. Instrumentation I-9, No. 2, 231-236 (Sept. 1960).

Prompted by recent demands of Science and Technology, the Electricity Division of the National Bureau of Standards has entered a program for the accurate measurement of ratio and phase angle of current transformers at frequencies up to $10 \mathrm{kc} / \mathrm{s}$. The present paper describes a $1 / 1$ Standard Transformer having very small errors, designed to operate up to 100 percent overload from $60 \mathrm{c} / \mathrm{s}$ to $10 \mathrm{kc} / \mathrm{s}$, and the method used to establish its values to an accuracy of $5 \mathrm{ppm}$ and 6 microradians. The $1 / 1$ transformer and its assigned values of ratio and phase angles will serve as the basis for subsequent measurements and the evaluation of Standard Transformers of higher ratios.

Comparison of four different methods of determining drying shrinkage of concrete masonry units, J. O. Bryson and D. Watstein, J. Am. Concrete Inst. 58, No. 2, 163-184 (Aug. 1961).

Four different procedures for determining the drying shrinkage of concrete masonry units were compared in order to determine their suitability as possible standard test methods. The test procedures differed mainly by the conditions under which the specimens were dried and were designated $\mathrm{RT}-50$ $\left(73^{\circ} \mathrm{F}\right.$ and $50 \%$ R. H.), RT $-30\left(73^{\circ} \mathrm{F}\right.$ and $30 \%$ R. H.), Modified British $\left(122^{\circ} \mathrm{F}\right.$ and $17 \%$ R. H.), and Rapid $\left(220^{\circ}\right.$ $235^{\circ} \mathrm{F}$ ). In addition to varying the drying conditions, the size and shape of test specimens were also varied. The specimens were whole block, face shells cut in half lengthwise, thin laminas removed from the block at right angles to the face shell, and "remnant" block remaining after removal of the thin laminas.

The drying-shrinkage test was performed using all four procedures on both autoclaved and low-pressure steam cured block of sand and gravel, cinders, expanded slag, expanded shale, and pumic agrregates.

Considering the RT-50 Method as a basis of comparison, the ratios of the results obtained with the RT-30 Method to those obtained with the RT-50 specimens ranged from 0.68 to 1.20 while for the Modified British procedure these ratios ranged from 0.92 to 1.35 . For the Rapid Method, these ratios ranged from 1.22 to 3.82 .

Considerable reduction in the time required for completion of the shrinkage test at room temperature was achieved by the use of a method developed at the NBS employing thin specimens. 
Static and dynamic calibrations of pressure measuring instruments at the National Bureau of Standards, E. C. Lloyd and D. P. Johnson, Automatic and Remote Control Proc. 1st Intern. Congress of IF AC, 274-280 (1960).

Equipment developed or used at the National Bureau of Standards for pressure calibrations is described. For static calibrations this includes the controlled-clearance oil piston gage at high pressures, the air piston gage, the newly developed inclined air piston gage, and precision mercury columns. Use of a compact form of the tetrahedral anvil apparatus for investigation of polymorphic transitions to pressures above $100,000 \mathrm{~atm}$ is described. For dynamic pressure calibrations at pressures up to 3,500 atm a pressure-pulse generator of high amplitude accuracy is used, and for lower pressures the range of this equipment is overlapped by pressure pulses generated by a shock tube. The methods of use and the sources of error, and relative accuracies of these instruments are discussed.

The NBS absolute gravity experiment, D. R. Tate, Proc. $2 d$ Air Force Cambridge Research Center Military Geodesy Seminar, GRD Research Notes, 40 (Jan. 12-14, 1960).

The experiment to measure the acceleration due to gravity at the National Bureau of Standards is described. The determination is made by measuring the average speed of a freely falling object over two different but related distances. The object falls within a vacuum case which is itself falling with approximately the acceleration of gravity thus avoiding some of the practical difficulties of handling the object in a vacuum. The time over the two distances is determined by a photoelectric sensing unit and two erystal-controlled electronic timers reading to one-tenth of a microsecond. Lengths are measured not as lengths on an object but as the distances the object must move to trigger the timers on and off.

Computer for weather data acquisition, P. Meissner, J. Cunningham, and C. Kettering, Proc. Eastern Joint Computer Conf. 18, No. 2.1, 5\%-66 (Dec. 1960).

In order to meet a growing need for more rapid and detailed reporting of weather information, the U.S. Weather Bureau has been conducting an extensive program for the development of automatic weather stations. The National Bureau of Standards has had an opportunity to participate in this program and has developed a small, specialized computer for use as the control component in such a station. The computer is intended as a research tool for exploring the application of automatic data processing equipment to this type of problem. Basically, the computer must sample a number of weather-sensing instruments, suitably process the instrument data, and prepare outputs in the form of local displays and teletype messages. Since the machine is internally programmed, it will afford a wide latitude in the processing of input data including the simultaneous comparison of results obtained in different ways.

The design of a computer for this application was felt to be justified on the basis of a number of special requirements. Among these are:

1) parallel inputs from a number of separate sources,

2) multiple outputs in several forms,

3) concurrent operation of input, output, and dataprocessing functions,

4) extensive reference tables with special instructions for their use,

5) limited arithmetic capability,

6) three-digit word length,

7) computing speed need not be high.

Location of the plane of best average definition for airplane camera lenses, F. E. Washer and W. P. Tayman, Photogrammetric Eng. 26, No. 3, 475-488 (1960).

The location of the plane of best average definition for lenses used in airplane mapping cameras is discussed. The effectiveness of the use of an average value of resolving power both as a means of locating the plane of best average definition and as a figure of merit in rating the optical performance of lenses and lens-camera combinations is investigated. Various methods of arriving at an average value of resolving power are described, such as area-weighted average resolution (AWAR), area and depth-of-focus weighted average resolution

(ADWAR), and root mean square mean resolution $\sqrt{R_{\beta} T_{\beta}}$. Location of the plane of best average definition by graphical analysis is given. A comparison of the various procedures using resolving power measurements obtained from four lenses with two emulsions are given. It is concluded that graphical analysis yields the most information and is simplest to use. Of the single-valued indices, such as AWAR, ADWAR, and $\sqrt{\bar{R}_{\beta} T_{\beta}}, \mathrm{ADWAR}$ is the best suited for locating the plane of best average definition. In using any of the indices as a rating factor, careful judgment is necessary if the rating is to be significant.

Humidity standards, A. Wexler, Tappi 44, No. 6, $180 a$ (June 1961).

This paper describes and discusses instruments which may serve as primary and secondary humidity standards, including a gravimetric hygrometer, now under development at the National Bureau of Standards, to serve as its basic reference for humidity measurements. The use of precision humidity generators for producing atmospheres of known humidity is outlined. Methods and techniques of obtaining fixed humidity points are given.

A high-resolution ammonia-maser-spectrum analyzer, J. A. Barnes and L. E. Heim, IRE Trans. Instrumentation I-10, 4-8 (June 1961)

A quartz crystal oscillator was phase locked to an ammonia beam maser to give a sufficiently monochromatic signal to enable the measurement of power spectra of other crystal oscillators multiplied from 1458 to 145,800 times in frequency. The perturbing effects of amplifiers introduced in the early stages of multiplication were observed. It was found that for maximum purity, de filaments on the oscillator and early stages of multiplication were essential. With this system it was possible to investigate sidebands and noise on various oscillators and determine which oscillators were most suited for precise frequency measurements with the National Bureau of Standards atomic frequency standards.

Pulse voltage comparator measures height of positive or negative pulses, O. B. Laug, Electronics 34, No. 36, $\gamma_{0}-\gamma_{1}$ (Sept. 1961).

A voltage comparator is described which responds to either positive or negative pulses of short duration by closing a relay. The comparator responds accurately to pulse widths of 50 nano sec. or greater and duty factors as low as $10^{-7}$. The basic circuit consists of two series triggered blocking oscillators coupled to a switching circuit driving a relay. The effect of temperature on the 1 volt threshold is compensated by forward biased diodes. The nominal threshold voltage is held within $0.5 \%$ from 0 to $50{ }^{\circ} \mathrm{C}$ for positive pulses.

Digest of A general description of d-c digital voltmeters, C. Stansbury, AIEE Trans. Paper 61-721 (Apr. 1961).

The widespread use of measurement transducers producing continuously varying voltage signals has led to extensive development of apparatus for the conversion of such signals to digital form. The term "digital voltmeter" is applied to the class of such converters having as primary function the direct visual indication of voltage in the form of decimal digits.

The advantages of digital voltmeters include feasibility of high accuracy superiority of reading characteristics, adaptability to code recording. Disadvantages include high cost and complexity and relatively low reliability compared to conventional scale-type instruments.

The paper describes the design features common to all types, and the various voltage-comparison mechanisms commonly employed. Performance characteristics are discussed, in cluding accuracy considerations, coordination of resolution with accuracy and calibration.

It has been evident for some time that this field of instrumentation would benefit greatly from a degree of industrial standardization consistent with that existing for the older types of instrument. An ASA committee sponsored by AIEE, IRE, and NBS, has been organized for this purpose. 


\section{Other NBS Publications}

Journal of Research 65A (Phys. and Chem.) No. 6 (Nov.-

Dec. 1961). 70 cents.

Comparison of lens response for sinusoidal and square-wave targets at several focal positions. S. H. Emara.

Wavelength shifts in $\mathrm{Hg}^{198}$ as a function of temperature. H. Emara.

Variability of spectral tristimulus values. I. Nimeroff, J. R. Rosenblatt, and M. C. Dannemiller.

Extension of the Flory-Rehner theory of swelling to an anisotropic polymer system. S. D. Bruck.

Fiber structure-property relationships: a disulfide-crosslinked self-crimping polyamide. S. D. Bruck.

Acidity functions. Values of the quantity $p\left(a_{\mathrm{H}} \gamma_{\mathrm{C} 1}\right)$ for buffer solutions from 0 to $95{ }^{\circ} \mathrm{C}$. R. G. Bates and R. Gary.

$2,3-0$-Isopropylidene- $\alpha$-D-lyxofuranose, the monoacetone-Dlyxose of Levene and Tipson. R. Schaffer.

Effect of perchloryl fluoride additions on the flame speed of methane. C. Halpern.

Journal of Research 66A (Phys. and Chem.) No. 1 (Jan.-Feb.

1962). 70 cents.

Absolute isotopic abundance of terrestrial silver. W. R. Shields, E. L. Garner, and V. H. Dibeler.

Temperature of a copper arc. C. H. Corliss.

Melting process and the equilibrium melting temperature of polychlorotrifluoroethylene. J. D. Hoffman and J. J Weeks.

Tritium-labeled compounds VIII. Confirmation of the position of the tritium in D-glucose-6-t and D-glucitol-5-t. L. T.Sniegoski and H. S. Isbell.

Infrared absorption spectra in the study of mutarotational equilibria of monosaccharides. R.S. Tipson and H.S. Isbell

Preparation of high purity trimethylborane. G. S. Ross, D. Enagonio, C. A. Hewitt, and A. R. Glasgow.

Reaction of several aminopvrimidines with formaldehyde. G. L. McLeod.

Acidic dissociation constant and related thermodynamic quantities for diethanolammonium ion in water from 0 to $50{ }^{\circ} \mathrm{C}$. V. E. Bower, R. A. Robinson, and R. G. Bates.

Fiber structure-property relationships II: Macroscopic deformations of alkylene sulfide crosslinked polycaprolactam fibers. S. D. Bruck.

Ion transport across membranes: I. Definitions of membrane electromotive forces and of flows of electrolytic solutes. B. C. Duncan.

Journal of Research 65B (Math. and Math. Phys.) No. 4 (Oct.-Dec. 1961). 75 cents.

Physical entities and mathematical representation. C. H Page. (See above abstract.)

On the range of a fleet of aircraft. A. J. Goldman.

Measurement of wave fronts without a reference standard: Part I. The wave-front-shearing interferometer. J. B. Saunders.

On the evaluation of the function $\Phi(\lambda)=\frac{1}{2 \pi i} \int_{\sigma-i \infty}^{\sigma+i \infty} e^{u \ln u+\lambda u} d u$ for real values of $\lambda$. W. Börsch-Supan.

Analyticity and probability properties of one-dimensional Brownian motion. A. Ghaffari.

Some higher order integral identities with application to bounding techniques. J. H. Bramble and B. E. Hubbard.

A priori bounds in the first boundary value problem in elasticity. J. H. Bramble and L. E. Payne.

Journal of Research 66D (Radio Prop.) No. 1 (Jan.-Feb. 1962). 70 cents.

A survey of the very wide band and frequency independent antennas - 1945 to the present. J. D. Dyson.

Numerical investigation of the equivalent impedance of a wire grid parallel to the interface between two media. T. Larsen.

Current on and input impedance of a cylindrical antenna. M. Chen and J. B. Keller.

Radar corner reflectors for linear or circular polarization. Latmiral and A. Sposito.

On the theroy of wave propagation through a concentrically stratified troposphere with a smooth profile. H. Bremmer.
On the propagation of VLF and ELF radio waves when the ionosphere is not sharply bounded. J. R. Wait.

Fields of electric dipoles in sea water - the earth-atmosphereionosphere problem. W. L. Anderson.

Reflection of electromagnetic waves from thin ionized gaseous layers. F. H. Northover.

Reflection and transmission of radio waves at a continuously stratified plasma with arbitrary magnetic induction. J. R. Johler and J. D. Harper, Jr.

On the diffraction of spherical radio waves by a finitely conducting spherical earth. L. C. Walters and J. R. Johler.

An approximate full wave solution for low frequency electromagnetic waves in an unbounded magneto-ionic medium. W. C. Hoffman.

VHF radio propagation data for the Cedar Rapids-Sterling, Anchorage-Barrow, and Fargo-Churchill test paths, April 1951 through June 1958. G. R. Sugar and K. W. Sullivan.

Capacities of stacks in sanitary drainage systems for buildings, R. W. Wyly and H. N. Eaton, NBS Mono. 31 (1961), 35 cents.

International practical temperature scale of 1948 , text revision of 1960, H. F. Stimson, NBS Mono. 37 (1961), 10 cents.

Stopping powers for use with cavity chambers, NBS Handb. 79 (1961), 35 cents.

Hydraulic research in the United States, H. K. Middleton, NBS Mich. Publ. 238 (1961), $\$ 1.25$

Fractional factorial designs for experiments with factors at two and three levels, W. S. Connor and S. Young, NBS Applied Math. Series 58 (1961), 40 cents

Quarterly radio noise data, March, April, May 1961, W. Q. Crichlow, R. T. Disney, and M. A. Jenkins, NBS Tech. Note 18-10 (PB151377-10) (1961) \$1.50.

Mean electron density variations of the quiet ionosphere 4 June 1959, J. W. Wright, L. R. Wescott, and D. J. Brown, NBS Tech. Note 40-4 (PB151399-4) (1961) \$1.50.

Mean electron density variations of the quiet ionosphere, No. 5-July 1959, J. W. Wright, L. R. Wescott, and D. J. Brown, NBS Tech. Note 40-5 (PB151399-5) (1961) $\$ 1.50$.

An evaluation of Kacser's second order Born approximation to the bremsstrahlung differential cross section, G. S. Ofelt, NBS Tech. Note 81 (PB161582) (1961) 75 cents.

Collisions of liquid drops with liquids, O. G. Engel, NBS Tech. Note 89 (PB161590) (1961) \$1.00.

Flux switching mechanisms in ferrite cores and their dependence on core geometry, G. W. Reimherr, NBS Tech. Note 90 (PB161591) (1961) \$1.25.

Determination of the $\mathrm{K}$ fluorescence vield of argon by proportional-counter spectrometry, C. Godeau, NBS Tech. Note 91 (PB161592) (1961) 50 cents.

An experimental study of beta decay using the radiations from oriented nuclei, D. D. Hoppes, NBS Tech. Note 93 (PB161594) (1961) \$1.50

Bibliography on meteoric radio wave propagation, W. Nupen, NBS Tech. Note 94 (PB161595) (1961) \$2.75.

On the climatology of ground-based radio ducts and associated fading regions, E. J. Dutton, NBS Tech. Note 96 (PB161597) (1961) $\$ 1.75$

The integrated starlight over the sky, L. R. Megill and F. E. Roach, NBS Tech. Note 106 (PB161607) (1961) \$2.00.

A fixed frequency, $9.1 \mathrm{Gc}$, field intensity recording receiver with extremely narrow bandwidth, R. W. Hubbard and J. V. Cateora, NBS Tech. Note 107 (PB161608) (1961) 75 cents.

A compilation of the physical equilibria and related properties of the hydrogen-carbon monoxide system, D. E. Drayer and T. M. Flynn, NBS Tech. Note 108 (PB161609) (1961) $\$ 2.25$

A compilation of the physical equilibria and related properties of the hydrogen-helium system, D. E. Drayer and T. M. Flynn, NBS Tech. Note 109 (PB161610) (1961) \$1.25.

A compilation of the physical equilibria and related properties of the hydrogen-nitrogen system, D. E. Drayer and T. M Flynn, NBS Tech. Note 110 (PB161611) (1961) \$1.75.

Data reduction instrumentation for radio propagation research, W. E. Johnson, NBS Tech. Note 111 (PB161612) (1961) \$1.00. 
Load carrying capacity of gas-lubricated bearings with inherent orifice compensation using nitrogen and helium gas, H. Sixsmith, W. A. Wilson, and B. W. Birmingham, NBS Tech. Note 115 (PB161616) (1961) \$1.00.

Vapor phase gamma-radiolysis of azomethane, L. J. Stief and P. Ausloos, J. Phys. Chem. 65, 877-881 (1961).

Electron interferometer studies of iron whiskers, H. A. Fowler, L. Marton, J. A. Simpson, and J. A. Suddeth, J. Appl. Phys. 32, No. 6, 1153 (June 1961).

Changes in dentures during storage in water and in service, J. B. Woefel, G. C. Paffenbarger, and W. T. Sweeney, J. Am. Dental Assoc. 62, No. 6, 643-657 (June 1961).

Solar disturbances and radio communication forecasts, J. F. Brockman, Sky and Telescope, XXI, No. 6, 322-326 (June 1961).

Dissociation constant of the protonated acid form of 2-Amino2-(hydroxymethyl)-1, 3-propanediol [tris(hydroxymethyl)aminomethane] and related thermodynamic quantities from 0 to $50^{\circ}$, R. G. Bates and H. B. Hetzer, J. Phys. Chem. 65, 667-671 (1961).

Hyperfine structure and isotope shifts in the 2537-A line of mercury, W. G. Schweitzer, Jr., J. Opt. Soc. Am. 51, No. 6, 692-693 (June 1961)

Long-distance one-hop $\mathrm{F}_{1}$ propagation through the auroral zone, L. H. Tveten, J. Geophys. Research 66, No. 6, 1683 1684 (June 1961)

Resonators for millimeter and submillimeter wavelengths, W. Culshaw, IRE Trans. Microwave Theory and Tech. MTT-9, No. 2, 135-144 (March 1961)

Paramagnetic substances for nuclear orientation, R. P. Hudson, Prog. in Cryogenics 3, 99-127 (1961).

A five-attribute system of describing visual appearance, D. B. Judd, Am. Soc. Testing Materials Spec. Tech. Pub. No. 297 (1961)

Solar flare effects in the $\mathrm{F}$ region of the ionosphere, R. W. Knecht and K. Davies, Nature 190, No. 4778, 797-798 May 1961)

Age to indium resonance for $\mathrm{D}-\mathrm{D}$ neutrons in heavy water V. Spiegel, Jr., and A. C. B. Richardson, Nuclear Sci. and Eng. 10, No. 1, 11-15 (1961)

Magnetic properties and optical absorption spectrum of K $\mathrm{ReCl}_{6}$, J. C. Eisenstein, J. Chem. Phys. 34, No. 5, 1628 1648 (May 1961).

Convective circulation in water induced by evaporation cooling, W. G. Spangenberg and W. R. Rowland, Phys. of Fluids 4, No. 6, 743-750 (June 1961).

Photoionization heating in the $\mathrm{F}$ region of the atmosphere, D. C. Hunt and T. E. Van Zandt, J. Geophys. Research 66, No. 6, 1673-1682 (June 1961).

Identification of fiber blends by infrared spectroscopy, M. K. Wharton and F. H. Forziati, Am. Dyestuff Rep. 50, No. 14, 33-36 (July 1961)

Calculations of the neutron age in water and heavy water for D-D sources, J. W. Cooper, Nuclear Sci. and Eng. 10, No. 1, 1-10 (May 1961).

Magnetic susceptibility of cerous magnesium Nitrate, R. P. Huds on and W. R. Hosler, Phys. Rev. 122, No. 5, 1417 1420 (June 1961).

Use of gaussian orbitals for atoms-in-molecule calculations, M. Kraus, J. Chem. Phys. 34, No. 2, 692-693 E (February 1961).

Measurement of minority carrier lifetime in $\mathrm{SiC}$ by a novel electroluminescent method, G. G. Harman and R. L. Raybold, J. Appl. Phys. 32, No. 6, 1168-1169 (June 1961).

Absolute measurement of $\mathrm{W}$ for $\mathrm{Po}^{210}$ alpha particles in air, nitrogen and carbon dioxide, Z. Bay, P. A. Newman, and H. H. Seliger, Radiation Research 14, No. 5, 551-565 (May 1961).

The structure of the monoclinic form of sodium tetrametaphosphate tetrahydrate, H. M. Ondik, C. H. MacGillavry, and S. Block, Acta. Cryst. 14, 555 (1961).

A comparison between theoretical and experimental data on phase velocity of VLF radio waves, J. R. Wait, Proc. IRE 49, No. 6, 1089-1090 (June 1961)

A diffraction theory for LF sky-wave propagation, J. R Wait, J. Geophys. Research 66, No. 6, 1713-1724 (June 1961); An additional note, J. R. Wait and A. M. Conda. J. Geophys. Research 66, No. 6, 1725-1729 (June 1961).

Mass spectrometric study of cyanogen and cyanoacatylenes,
V. H. Dibeler, R. M. Reese, and J. L. Franklin, J. Am Chem. Soc. 83, 1813-1818 (1961).

Energy levels and magnetic dipole transitions in the $4 \mathrm{p}^{4}$ ground configuration of singly ionized atomic bromine ( $\mathrm{Br}$ II), W. C. Martin and J. L. Tech, J. Opt. Soc. Am. 51, No 6, 591-594 (June 1961).

An improved structure determination for vinyl fluoride, D R. Lide, Jr. and D. Christensen, Spectrochim. Acta 1\%, 665-668 (1961).

Incoherent scattering by free electrons as a technique for studying the ionosphere and exosphere: Some observations and theoretical considerations, K. L. Bowles, pp. 223-243 of AGARDograph 42, The upper atmosphere above $F 2$ maximum. North Atlantic Treaty Organization, Advisory Group for Aeronautical Research and Development, Avionics Panel. Papers presented at the Symposium of the Ionospheric Research Committee, Paris, France, May 1959 .

A $p \mathrm{H}$ standard for blood and other physiologic media, V. E. Bower, M. Paabo, and R. G. Bates, Clin. Chem. 7, No. 3 , 292 (June 1961).

Evidence on the laminar nature of the exosphere obtained by means of guided high-frequency wave propagation, R. M. Galley and W. F. Utlaut, Phys. Rev. Letters 6, No. 11, 591-594 (June 1, 1961).

Comparison of the ionization produced in air by alpha particles near 5 mev and by beta particles, $Z$. Bay and P. A. Newman, Radiation Research 14, No. 5, 566-572 (May 1961).

A century-old razor, S. J. Rosenberg, Metal Progress, 94-96 (1961).

Some applications of Hardy's formula in Brownian motion (Abstract), A. Ghaffari, Am. Math. Soc. Notices 8, No. 54, 238 (June 1961).

On the classical approximation in the statistical theory of mass spectra, H. M. Rosenstock, J. Chem. Phys. 34, 2182 (1961)

Superconductivity of $\mathrm{Nb}_{3} \mathrm{Sn}$ in pulsed fields of 185 kilogauss, V. D. Arp, R. H. Kropschot, and J. H. Wilson, Phys. Rev. Letters 6, No. 9, 452-453 (May 1961).

Proposed nomenclature for linear viscoelastic behavior, H. Leaderman and F. Schwarzl, Rheologica Acta, 1, No. 4/6, 674-676 (1961)

FM and SSB radiotelephone tests on a VHF ionospheric scatter link during multipath conditions, IRE Trans. Commun. Systems CS-8, No. 3, 183-186 (Sept. 1960).

Matrix elements in the forbidden beta decay of $\mathrm{Ce}^{141}, \mathrm{D}$. D. Hoppes, E. Ambler, R. W. Hayward, and R. S. Kaeser, Phys. Rev. Letters 6, 115-118 (1961)

The electromagnetic fields of horizontal dipole in the presence of a conducting half space, J. R. Wait, Can. J. Phys. 39, No. 7, 1017-1028 (July 1961).

4-Nitrophenyl esters, carbonates, and bi-carbonates as leather fungicides, S. Dahl and A. M. Kaplan, J. Am. Leather Chemists Assoc. 55, 480 (Sept. 1960).

The organization of international intercomparisons of radioactivity standards, with special reference to such measurements of NBS standards, L. M. Cavallo and W. B. Mann, Proc. 1959 Symp. Metrology Radioactive, IAEA, Vienna, $117(1960)$

The physical environment as affected by radiation, D. M. Gates, Proceedings of the 50th Anniversary Celebration of the University of Michigan Biological Station (1960). Second revision American Dental Association specifications No. 4 for dental inlay casting wax, J. W. Stanford, K. V. Weigel, and J. W. Paffenbarger, J. Am. Dental Assoc. 62, 45 (Jan. 1961)

The structure of B-type vibrational-rotational bands of an asymmetric rotor, H. C. Allen, Jr., Phil. Trans. Roy. Soc. of London, Series A, Mathematical and Physical Sciences, No. 1030, 253, 335 (1961).

Measurement of contrast in the aerial image, F. W. Rosberry, Photogrammetric Eng. 155-159 (March 1961)

Vapor-phase photolysis of formic acid, R. Gordon, Jr., and P. Ausloos, J. Chem. Phys. 65, 1033 (1961).

Binary silicate glasses in the study of alkali-aggregate reaction, R. G. Pike, D. Hubbard, and E. S. Newman, Highway Research Board Bull. No. 275, 39-44 (1960).

Complex conductivity of some plasmas and semiconductors, 
P. H. Fang, J. Appl. Research Soc. B (The Hague) 9, 51 (1960).

Physical measurement-challenge to science and engineering, A. V. Astin, SPE J. 17, No. 5, 455-458 (May 1961).

Dielectric properties of polyamides, A. J. Curtis, J. Chem. Phys. 34, No. 5, 1849-1850 (May 1961).

Natural and synthetic rubbers: Review of test methods, F. J. Linnig, M. Tryon, and E. J. Parks, Anal. Chem. 33, 127R (Apr. 1961)

Simple calculus for all-dielectric interference filters, K. D. Mielenz, J. Opt. Soc. Am. 50, No. 10, 1014 (Oct. 1960). Magnetic susceptibility of tetratonal titanium dioxide, F. E. Senftle, T. Pankey, and F. A. Grant, Phys. Rev. 120, 820 (Nov. 1960).

Equipment and procedures for the evaluation of total hemispherical emittance, J. C. Richmond and W. N. Harrison, Bull. Am. Ceram. Soc. 39, No. 11, 668 (Nov. 1960).

Limitations of radiosonde punch-card records for radiometeorological studies, B. R. Bean and B. A. Cahoon, J. Geophys. Research 66, No. 1, 328-331 (Jan. 1961).

Evaluations of some oxide glasses for use as infrared materials, G. W. Cleek and T. G. Scuderi, Proc. Infrared Information Symp. 5, No. 4 (Aug. 1960).

Improvement of some of the properties of sole leathers by impregnation with polymers, J. R. Kanagy, J. Am. Leather Chemists Assoc. LVI, No. 7, 322-342 (July 1961).

Studies on the flame-spraying of aluminum oxide, D. G. Moore, Metal Finishing J. 6, No. 70, 397 (Oct. 1960).

Four-color achromats and superchromats, R. E. Stephens, J. Opt. Soc. Am. 50, No. 10, 1016-1019 (Oct. 1960).

Bounds for determinants with positive diagonals, E. V. Haynsworth, Trans. Am. Math. Soc. 96, 395-399 (1960)

Refining measurements by capacitance techniques, F. K. Harris and R. D. Cutkosky, ISA-J. Instr. Soc. Am. 8, No. 2, 63-66 (Feb. 1961).

Standards for plastic pipe fittings, F. W. Reinhart, SPE J. 17, 160 (Feb. 1961)

Comparison of observed tropospheric refraction with values computed from the surface refractivity, B. R. Bean, IRE Trans. Ant. Prop. AP-9, 415-416 (July 1961).

Studies of enviromental factors in a family-size underground shelter, P. R. Achenbach, F. J. J. Drapeau, and C. W. Phillips, Report OCDM-NBS-60-1 issued Office of Civil Defense Mobilization (Mar. 1961).

Phase-shift method for one-dimensional scattering, A. H. Khan, Am. J. Phys. 29, 77 (1961).

Electric field distribution in a dense plasma, J. L. Jackson, Phys. Fluids 3, 927-931 (1960).

The classical field theories, C. Truesdell and R. Toupin, Handb. der Physik, Springer, Berlin, III, No. 1, 226-793 (1960).

Standards development by ASTM committee D-20 on plastics, F. Reinhart, SPE J. 16, 800 (Aug. 1960).

A nuclear magnetic resonance study of sny-anti isomerism in ketoximes, E. Lustig, J. Phys. Chem. 65, 491 (1961).

Evaluating the freezing-and-thawing durability of concrete by laboratory tests in the U.S.A., H. T. Arni and R. L Blaine, Preliminary Report on Symposium on Durability of Concrete of RILEM, Prague, Czechoslovakia, 218-231 (July 1961).

Spectroscopic standard samples of titanium and high-temperature alloys, R. E. Michaelis, J. Appl. Spectroscopy 15, 7 (1961).

Analytical laboratory problems, J. Mandel, Trans. Metropolitan Conf. Am. Soc. Quality Control, 99-107 (Feb. 1960).

Some experimental aspects of nuclear orientation, E. Ambler, Proc. 10th Inter. Congress of Refrigeration, Copenhagen, Denmark, 1959, Progress in Refrigeration in Science and Technology, I, 195-198 (Pergamon Press, London, England, 1960).

Absorption spectrum and magnetic properties of osmium hexaflouride, J. C. Eisenstein, J. Chem. Phys. 34, 310-318 (1961).

Rapid method for interpolating refractive index measuremets. O. N. Stavroudis and L. E. Sutton, J. Opt. Soc. Am. 51, No. 3, 368-370 (Mar. 1961).

Effect of departures from local thermodynamic equilibrium on inferences on stellar atmospheric temperatures, R. N. Thomas, Book, Optical Spectrometric Measurements of
High Temperatures, P. J. Dickerman, ed., 14-26 (University of Chicago Press, Chicago, Ill., 1961).

The retannage of chrome-tanned leather with vegetable tannins, J. R. Kanagy, J. Am. Leather Chemists Assoc, LVI, No. 6, 252-272 (June 1961).

Improved electron filter lens, J. A. Simpson and L. Marton, Rev. Sci. Instr. 32, No. 7, 802-803 (July 1961)

X-ray diffraction study of acellular teleost bone, M. L. Moss and A. S. Posner, Nature 188, 1037 (Dec. 1960).

Adsorption of polyesters and other polymers on glass and other substrates, R. R. Stromberg and G. M. Kline, Modern Plastics 38, 123 (Apr. 1961), 38, 241 (May 1961); Poliplastic 9, 15 (Jan.-Feb. 1961).

Tunnel diode large-signal simulation study, S. B. Geller and P. A. Mantek, Proc. IRE 49, No. 4, 803 (Apr. 1961).

Thermal degradation of organic polymers, S. L. Madorsky, Polymer Sci. 17, No. 7, (July 1961).

Determination of carboxyl in cellulose comparison of various methods, W. K. Wilson and J. Mandel, Tappi 44, No. 2, 131 (1961).

A recalibration of NBS carbon-14 standards by GeigerMuller and proportional gas counting, W. B. Mann, H. H. Seliger, W. F. Marlow, and R. W. Medlock, Rev. Sci. Instr. 31, No. 7, 690 (1960).

The solar spectrum from 2635 to 2085 A, H. H. Malitson, J. D. Purcell, R. Tousey, and C. E. Moore, Astrophys. J. 132, 746 (1960).

Winter thermal radiation studies in Yellowstone Park, D. M. Gates, Science 134, 32-35 (July 7, 1961).

Vapor phase $\gamma$-radiolysis of acetone, L. J. Stief and P. Ausloos, J. Phys. Chem. 65, 877 (1961).

Amine buffers for $p \mathrm{H}$ control, R. G. Bates, Ann. N. Y. Acad. Sci. 92, 341 (1961).

Cryogenic adhesive properties of bisphenol-A epoxy resins, M. J. Hiza and P. L. Barrick, SPE Trans. 1, 73-79 (Apr. 1961)

Resonance characteristics of a corrugated cylinder excited by a magnetic dipole, J. R. Wait and A. M. Conda, IRE Trans. Ant. Prop. AP-9, 330-333 (July 1961).

Infrared spectra of solid hydrocarbons at very low temperatures, J. J. Comeford and J. H. Gould, J. Mole Spectroscopy 5, 474 (1960).

Recent work with compensated internal gas counters for the standardization of gaseous radionuclides, W. B. Mann, Proc. Symp. Metrology of Radioactive, IAEA, Vienna, 307 (1960).

Vanadium oxytrichloride [Vanadyl(V) chloride], R. B. Johannesen, Book, Inorganic Syntheses, E. G. Rochow, Editor-in-Chief (McGraw-Hill Book Co., New York, N.Y.), IV. Chapt. 5B, No. 38, 119-120 (1960).

Concerning the potential refractive index and the molecular refractivity, B. R. Bean and J. D. Horn, J. Meteorol. 18, No. 3, 427-428 (June 1961).

Standard samples and related materials for spectrochemical analysis, R. E. Michaelis, Am. Soc. Testing Materials Spec. Tech. Publ. No. 58-D, 116 (1960).

Aromatic fluorocarbons: Thermal stability and synthesis, L. A. Wall, Proc. 6th Joint Army-Navy-Air Force Elastomer Conf., Oct. 18-20, 1960, I. 150 (U.S. Army Quartermaster Research \& Engineering Command, Natick, Mass.).

The Ionization constant of hydroxylamine, R. A. Robinson and V. E. Bower, J. Phys. Chem. 65, 1279-1280 (1961).

The calculation of the energy levels of nearly symmetric rotors, S. C. Wait, Jr., J. Mol. Spectroscopy 6, 276 (1960).

Multiple layer insulation for cryogenic applications, R. H. Kropschot, Cryogenies 1, 171-177 (Mar. 1961).

Extinguishment effectiveness of some powered materials on hydrocarbon fires, T. G. Lee and A. F. Robertson, Fire Research Abstracts and Reviews, Natl. Acad. Sci.-Natl. Research Council Publ. 786 (June 1961).

Forty years of dental research at the National Bureau of Standards, W. T. Sweeney, Capital Chemist 10, 228 (Oct. 1960).

A stainless steel for standard weights, S. J. Rosenberg and T. P. Royston, Materials Research \& Standards (ASTM Bull.) 1, No. 1, 21 (Jan. 1961).

Long-term working stress of thermoplastic pipe, F. W. Reinhart, SPE J. 751-754 (Aug. 1961). 
NBS atomic frequency standards, R. C. Mockler and R. E. Beehler, Proc. 14th Annual Symp. Frequency Control, Atlantic City, N.J., May 31-June 3, 1960, p. 298-309 (Signal Corps. Eng. Laboratories, Fort Monmouth, N.J., 1961)

Microwave Zeeman effect of free hydroxyl radicals: ${ }^{2} \mathrm{II}_{1 / 2}$ levels, H. E. Radford, Phys. Rev. 122, 114 (1961).

A precision RF power transfer standards, P. A. Hudson, IRE Trans. Instrumentation I-9, 280-283 (Sept. 1960).

The fluorescence and phosphorescence of trifluoroacetone vapor, P. Ausloos and E. Murad, J. Am. Chem. Soc. 83, 1327 (1961)

The morphology of sporadic E, E. K. Smith, Jr., Proc. XIIIth Gen. Assembly URSI (London, England, 1960), Natl. Acad. Sci.-Natl. Research Council Publ., Report No. 880, 218 (1961)

How to determine stack load limits, R. S. Wyly, Contractor, p. 19-20 (Aug. 15, 1961)

$\gamma$-Irradiation of liquid and solid oxygen, D. W. Brown and L. A. Wall, Phys. Chem. 65, 915 (1961).

Testing of ball bearings with five different separator materials at 9200 RPM in liquid nitrogen, J. A. Brennan, W. A. Wilson, R. Radebaugh, and B. W. Birmingham, Am. Soc. Mech. Engrs. No. 61-LUBS-18, 1-8 (Apr. 1961).

The CRPL electron density profile program: Some features and early results, J. W. Wright, Proc. URSI-AGI Symp. (Brussels, Belgium, 1959), Book, Some Ionospheric Results Obtained During IGY, Ed. W. J. G. Beyon (Elsevier Publ. Co., Princeton, N.J.), 215 (1960)

Kinetic isotope effects in the reaction of methyl radicals with ethane, $-d_{6}$ and ethane-1, 1, 1- $d_{3}$, J. R. MeNesby, J. Phys. Chem. 64, No. 11, 1671 (Nov. 1960).

Theory of vibrational relaxation in liquids, R. Z $Z_{\text {wanzig, J. }}$ Chem. Phys. 34, 1931-1935 (1961).

Nomenclature of carbohydrates, R. S. Tipson, J. Chem. Documentation 2, No. 3, 3-7 (1961).

Determination of wax in paper, W. L. Marrow, Tappi 44, No. 2, 120 (1961).

Mortar for cavity walls, C. C. Fishburn, Building Research Institute, 1960 Spring Conf. Program on Insulated Cavity Walls, Natl. Acad. Sci.-Nat. Research Council Publ. 793, $37(1960)$

Variations of [OI] $5577 \AA$ emission in the upper atmosphere, F. E. Roach, Ann. Geophys. 17, 172-180 (Apr.-June 1961).

Continuously operating $\mathrm{He}^{3}$ refrigerator for producing temperature down to $1 / 4^{\circ} \mathrm{K}$, E. Ambler and R. B. Dove, Rev. Sci. Instr. 32, No. 6, 737-739 (June 1961).

Density fluctuations and heat conduction in a pure liquid, R. E. Nettleton, Phys. Fluids 4, No. 1, 74 (Jan. 1961).

Low temperature properties of cerous magnesium nitrate, R. P. Hudson, R. S. Kaeser, and H. E. Radford, Proc. VIIth Intern. Conf. Low Temperature Physics, University of Toronto, Canada, pp.45-48 (1960).

The oxide films formed on copper single crystal surfaces in water II. Rate of growth at room temperature, J. Kruger, J. Electrochem. Soc. 108, No. 6, 503 (June 1961).

A review of the hydraulics of circular sewers in accordance with the Manning formula, R. S. Wyly, Yearbook of Am. Soc. of Sanitary Engineering 38, 154 (1960).

Line shape of ultraviolet absorption in solid noble gases, P. H. E. Meijer, J. Chem. Phys. 34, 2078-2082 (1961). Non-reciprocity and time-reversal in microwave circuits, H. A. Fowler, Academie royale de Belgique (Classe Des Sciences) V-46, No. 11, 963-977 (Dec. 1960).

A screening method for large information retrieval systems, R. T. Moore, Proc. Western Joint IRE-AIEE-ACM Computer Conf., Los Angeles, Calif. 6.3, 259-274 (1961).

Tchebycheff approximations by $a b^{x}+c$, J. R. Rice, J. Soc. Ind. Appl. Math. 8, No. 4, 691-702 (1960).

Ionospheric "forward" scattering, D. K. Bailey, Proc. XIIIth Gen. Assembly of URSI (London, England, 1960), Natl. Acad. Sci.-Natl. Research Council Publ. Report No. 880, 281 (1961).
Apparatus for controlled slack quenching, N. L. Carwile, M. R. Meyerson, and S. J. Rosenberg, Materials Research and Standards (ASTM Bull.) 1, No. 7, 532-536 (July 1961).

Exponential temperature dependence of Young's modulus for several oxides, J. B. Watchman, Jr., W. E. Tefft, D. G. Lam, Jr., and C. S. Apstein, Phys. Rev. 122, 1754 (June 1961).

Electron spin resonance spectra of free-radical intermediates formed by reaction of polystyrene with atoms of hydrogen and deuterium, R. B. Ingalls and L. A. Wall, J. Chem. Phys. 35, No. 1, 370-371 (July 1961).

The X- or gamma-ray energy absorption of transfer coefficient: Tabulations and discussion, R. T. Berger, Radiation Research 15, No. 1, 1-29 (July 1961)

Reinhart, F. M., Twenty-year atmospheric corrosion investigation of zinc-coated and uncoated wire and wire products, Am. Soc. Testing Materials Spec. Tech. Publ. 290, 1-141 (June 1961).

Time standards, A. G. MeNish, Instr. and Control Systems 33, 1340-1341 (Aug. 1960).

Adsorption of nitrogen and argon on mineralogical graphite and diamond at 77 and $90^{\circ} \mathrm{K}$, J. de Dios Lopez-Gonzalez, F. G. Carpenter, and V. R. Deitz, J. Phys. Chem 65, No. 7 , 1112-19 (July 1961)

Absorption of carbon dioxide by solutions of 2-amino-2(hydroxymethyl)-1, 3-propanediol, R. G. Bates and H. B. Hetzer, Anal. Chem. 33, No. 9, 1285 (Aug. 1961).

Stress-strain relationships in yarns subjected to rapid impact loading; Part 7. Stress-strain curves and breaking-energy data for textile yarns, J. C. Smith, P. J. Shouse, J. M. Blandford, and K. M. Towne, Textile Research J. 31, No. 8, 721-734 (Aug. 1961)

V. Mutual interference between surfaces and satellite communication systems, B. Hartman, M. T. Decker, Chapt. 5 , p. 111-157, Book, Frequency Allocations for Space Communications (Report of the Joint Tech. Adv. Comm. of IRE-EIA to the Federal Communications Commission, (Mar. 1961).

Quantum theory of interference effects in the mixing of light from phase-independent sources, U. Fano, Am. J. Phys. 29, No. 8, 539-545 (August 1961)

Heats and volumes of mixing in several $\mathrm{C}_{12}$ hydrocarbon systems, R. S. Jessup and C. L. Stanley, J. Chem. Eng. Data 6, No. 3, 368-371 (July 1961).

Some observations of copper deposits on single crystals of copper, I. Giron and F. Ogburn, J. Electrochem. Soc. 108, No. 9, 842-846 (Sept. 1961).

Binary oxide systems, H. R. Hoekstra and H. S. Parker, Chapt. 6, Sect. 6, p. 271-304, Book, $\mathrm{UO}_{2}$, Properties and Nuclear Applications (U.S. Superintendent of Documents, Government Printing Office, Washington 25, D.C., Aug. 1961).

Wind resistance of asphalt shingle roofing, W. C. Cullen, Natl. Acad. Sci.-Natl. Research Council, 33-42 (1961).

Spectroscopic observations of the stratosphere and mesosphere D. M. Gates, Instr. Soc. Am. J. Conf. Preprint No. 2-NY60 (Sept. 1960).

Supercooling in the barnyard, C. P. Saylor, Capital Chemist 10, No. 9, 292-293 (Dec. 1960).

Low-angle X-ray diffraction of crystalline nonoriented polyethylene and its relation to crystallization mechanisms, L. Mandelkern, A. S. Posner, A. F. Diorio, and D. E. Roberts, J. Appl. Phys. 32, No. 8, 1509-1517 (Aug. 1961). References to contemporary papers on acoustics, W. Koidan, Acoust. Soc. Am. 33, No. 5, 705-716 (May 1961).

*Publications for which a price is indicated (except for Technical Notes) are available only from the Superintendent of Documents, U.S. Government Printing Office, Washington 25, D.C. (foreign postage, one-fourth additional). Technical Notes are available only from the Office of Technical Services, U.S. Department of Commerce, Washington 25, D.C. (Order by PB number.) Reprints from outside journals and the NBS Journal of Research may often be obtained directly from the authors. 